\title{
Article
}

http://dx.doi.org/10.11646/phytotaxa.233.1.2

\section{Taxonomy and phylogeny of Cercospora spp. from Northern Thailand}

\author{
JEERAPA NGUANHOM ${ }^{1}$, RATCHADAWAN CHEEWANGKOON ${ }^{1}$, JOHANNES Z. GROENEWALD ${ }^{2}$, UWE \\ BRAUN $^{3}$, CHAIWAT TO-ANUN ${ }^{1 *} \&$ PEDRO W. CROUS ${ }^{2,4}$ \\ ${ }^{1}$ Department of Entomology and Plant Pathology, Faculty of Agriculture, Chiang Mai University, 50200, Thailand \\ *email: chaiwat.toanun@gmail.com \\ ${ }^{2}$ CBS-KNAW Fungal Biodiversity Centre, Uppsalalaan 8, 3584 CT Utrecht, The Netherlands \\ ${ }^{3}$ Martin-Luther-Universität, Institut für Biologie, Bereich Geobotanik und Botanischer Garten, Herbarium, Neuwerk 21, 06099 Halle \\ (Saale), Germany \\ ${ }^{4}$ Department of Microbiology and Plant Pathology, Forestry and Agricultural Biotechnology Institute, University of Pretoria, Pretoria \\ 0002, South Africa
}

\begin{abstract}
The genus Cercospora represents a group of important plant pathogenic fungi with a wide geographic distribution, being commonly associated with leaf spots on a broad range of plant hosts. The goal of the present study was to conduct a morphological and molecular phylogenetic analysis of the Cercospora spp. occurring on various plants growing in Northern Thailand, an area with a tropical savannah climate, and a rich diversity of vascular plants. Sixty Cercospora isolates were collected from 29 host species (representing 16 plant families). Partial nucleotide sequence data for two gene loci (ITS and $c m d A$ ), were generated for all isolates. Results from this study indicate that members of the genus Cercospora vary regarding host specificity, with some taxa having wide host ranges, and others being host-specific. Based on cultural, morphological and phylogenetic data, four new species of Cercospora could be identified: C. glycinicola (from Glycine max), C. cyperacearum and C. cyperina (from Cyperus alternifolius), and C. musigena (from Musa sp.). The most common Cercospora sp. found in Northern Thailand was $C$. cf. malloti, which occurred on a wide host range. Several collections could not be resolved to species level due to the lack of reference cultures and DNA data for morphologically similar species. Further collections from other countries are needed to help resolve the taxonomy of some species complexes occurring on various plant hosts in Thailand.
\end{abstract}

Key words: biodiversity, cercosporoid hyphomycetes, Mycosphaerellaceae, phylogeny

\section{Introduction}

Species of Cercospora (Mycosphaerellaceae, Capnodiales) commonly occur associated with leaf and fruit spots on a range of cultivated and wild plants worldwide (Crous \& Braun 2003, Groenewald et al. 2013, Amaradasa et al. 2014, Bakhshi et al. 2015b). To date there have been several studies focused on these fungi in Thailand, and more than 500 cercosporoid species have been identified (Giatgong 1980, Sontirat et al. 1980, Petcharat \& Kanjanamaneesathian 1989, Braun et al. 2006, Meeboon et al. 2007a, 2007b, 2007c, 2008, Nakashima et al. 2007, Phengsintham et al. 2013). However, almost all these studies have thus far relied exclusively on morphological data, and very few records are supported by cultures and DNA data. The first application of DNA phylogenetic analysis (ITS) to distinguish Cercospora species from Thailand was published by To-anun et al. (2010, 2011). In other studies multi-locus DNA data proved highly effective to distinguish among species of cercosporoid fungi (Groenewald et al. 2013, Crous et al. 2013, Bakhshi et al. 2015a, 2015b). The same approach also proved successful to study other, related, cercosporoid genera from Thailand (Hunter et al. 2006, Cheewangkoon et al. 2008). To date, however, most cercosporoid records from Thailand cannot be substantiated based on a lack of cultures and DNA data. The main objective of the present study was therefore to confirm the identification of different Cercospora spp. associated with various plant diseases from Northern Thailand, and to resolve their taxonomy and DNA phylogeny. 


\section{Materials and methods}

\section{Isolates}

Specimens with disease symptoms were collected in the field and taken to the laboratory for fungal isolation. Leaves were examined directly using a dissecting microscope to observe Cercospora conidiophore fascicles, or when insufficiently developed, incubated in moist chambers for $1-2 \mathrm{~d}$ to induce sporulation. Single conidium colonies were established on Petri dishes containing 2\% malt extract agar (MEA) as described by Crous et al. (2009). Reference strains are maintained at the working collection of P.W. Crous (CPC), with representative isolates deposited in the CBS-KNAW Fungal Biodiversity Centre (CBS), Utrecht, The Netherlands (Table 1).

\section{DNA extraction, amplification and sequencing}

Genomic DNA was extracted from fungal mycelium growing on MEA, placed in a 2-ml Eppendorf tube with $600 \mu 1$ hexadecyltrimethyl ammonium bromide (CTAB) extraction buffer (500 $\mu$ l of TES Buffer (100 mM Tris pH 8; $10 \mathrm{mM}$ EDTA pH $8 ; 2 \% \mathrm{SDS}$ ), $140 \mu \mathrm{l}$ of $5 \mathrm{M} \mathrm{NaCl}$ and $65 \mu \mathrm{l}$ of $10 \% \mathrm{CTAB}$ solution) and mixed well (protocol modified from Möller et al. 1992). To break the cells, the tube was placed in a boiling water bath for $3 \mathrm{~min}$, after which it was chilled directly on ice for $10 \mathrm{~min}$. Four hundred microliters of chloroform:isoamyl alcohol (24:1) were added and mixed properly by inversion, and centrifuged at 14,000 rpm for $5 \mathrm{~min}$ at room temperature to separate the phases. The upper phase was carefully collected and transferred to a new $2 \mathrm{ml}$ tube. An equal volume of cold $5 \mathrm{M}$ ammonium acetate was added and the gDNA precipitated with $600 \mu \mathrm{l}$ of cold isopropanol and inverted. After 15 min incubation on ice, the solution was centrifuged at 14,000 rpm for $5 \mathrm{~min}$ and the supernatant discarded. The pellet was washed with $70 \%$ ethanol, air-dried and resuspended in $100 \mu \mathrm{l}$ of TE buffer.

All isolates were sequenced for two genomic loci, namely the internal transcribed spacer region with intervening 5.8S nrRNA gene (ITS) and partial calmodulin gene ( $\mathrm{cmdA}$ ). The primer ITS5 (White et al. 1990) or V9G (de Hoog \& Gerrits van den Ende 1998) and ITS4 (White et al. 1990) were used to amplify the ITS and the primer set CAL-228F and CAL-737R (Carbone \& Kohn 1999) or CAL2Rd (Groenewald et al. 2013) for $\mathrm{cmdA}$. The reaction mixture had a total volume of $12.5 \mu \mathrm{l}$ containing $1 \mu \mathrm{l}$ diluted DNA, $1 \times$ PCR buffer, $2 \mathrm{mM} \mathrm{MgCl}, 25 \mu \mathrm{M}$ of each dNTPs, $1 \mu \mathrm{M}$ of each primer, and 0.5 U Taq DNA polymerase (GoTaq, Promega). The amplification reactions were done on a 2720 Thermal Cycler (Applied Biosystems). PCR amplification conditions for ITS were set as follows: an initial denaturation temperature of $94^{\circ} \mathrm{C}$ for $5 \mathrm{~min}$, followed by 35 cycles of denaturation temperature of $94^{\circ} \mathrm{C}$ for $45 \mathrm{~s}$, primer annealing at $48^{\circ} \mathrm{C}$ for $45 \mathrm{~s}$, primer extension at $72^{\circ} \mathrm{C}$ for $2 \mathrm{~min}$ and a final extension step at $72^{\circ} \mathrm{C}$ for $7 \mathrm{~min}$. PCR amplification conditions for $\mathrm{cmdA}$ were set as follows: an initial denaturation temperature of $94^{\circ} \mathrm{C}$ for $3 \mathrm{~min}$, followed by 35 cycles of denaturation temperature of $94^{\circ} \mathrm{C}$ for $30 \mathrm{~s}$, primer annealing at $58^{\circ} \mathrm{C}$ for $40 \mathrm{~s}$, primer extension at $72^{\circ} \mathrm{C}$ for $50 \mathrm{~s}$ and a final extension step at $72^{\circ} \mathrm{C}$ for $5 \mathrm{~min}$. The PCR products were separated by electrophoresis at $100 \mathrm{~V}$ for $30 \mathrm{~min}$ on a $1 \%(\mathrm{w} / \mathrm{v})$ agarose gel stained with GelRed in $1 \times$ TAE buffer $(0.4 \mathrm{M}$ Tris, $0.05 \mathrm{M} \mathrm{NaAc}$, and $0.01 \mathrm{M}$ EDTA, pH 7.85) and visualized under UV light.

The resulting fragments were sequenced in both directions with the various PCR primers using a BigDye ${ }^{\circledR}$ Terminator Cycle Sequencing Kit v. 3.1 (Applied Biosystems, Foster City, CA) and analysed on an ABI Prism 3100 DNA Sequencer (Perkin-Elmer, Norwalk, CN).

\section{Phylogenetic analyses}

A consensus sequence was computed from the forward and reverse sequences using SeqMan from the Lasergene package (DNASTAR, Madison, Wisconsin). The consensus sequence was added to the alignment using MAFFT v. 7 (http://mafft.cbrc.jp/alignment/server/index.html; Katoh \& Standley 2013) and manually improved in MEGA v. 5 (Tamura et al. 2011). MrModeltest v. 2.3 (Nylander 2004) was used to determine the best nucleotide substitution model setting for each locus.

The phylogenetic analyses of sequence data were performed in MrBayes v. 3.2.1 (Ronquist et al. 2012). The optimal substitution model for each locus, as recommended by MrModeltest, was implemented. The heating parameter was set at 0.3 and the Markov Chain Monte Carlo (MCMC) analysis of four chains was started in parallel from a random tree topology and lasted until the average standard deviation of split frequencies reached 0.01 . Trees were saved each 1,000 generations and the resulting phylogenetic tree was printed with Geneious v. 5.5.4 (Drummond et al. 2011). New sequences generated in this study were submitted to GenBank (accession numbers listed in Table 1) and the alignment and phylogenetic tree to TreeBASE (ID 17818; www.treebase.org). 


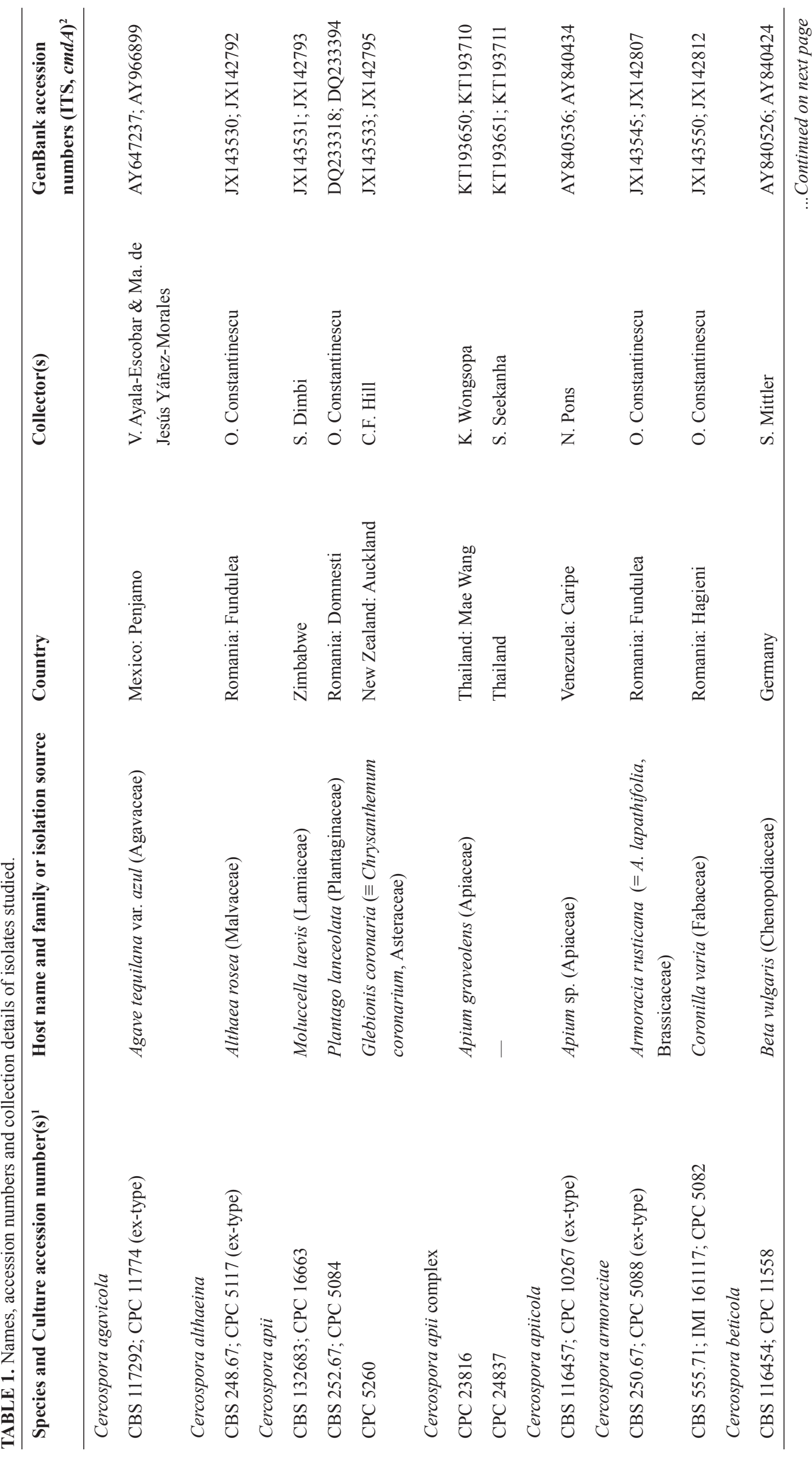




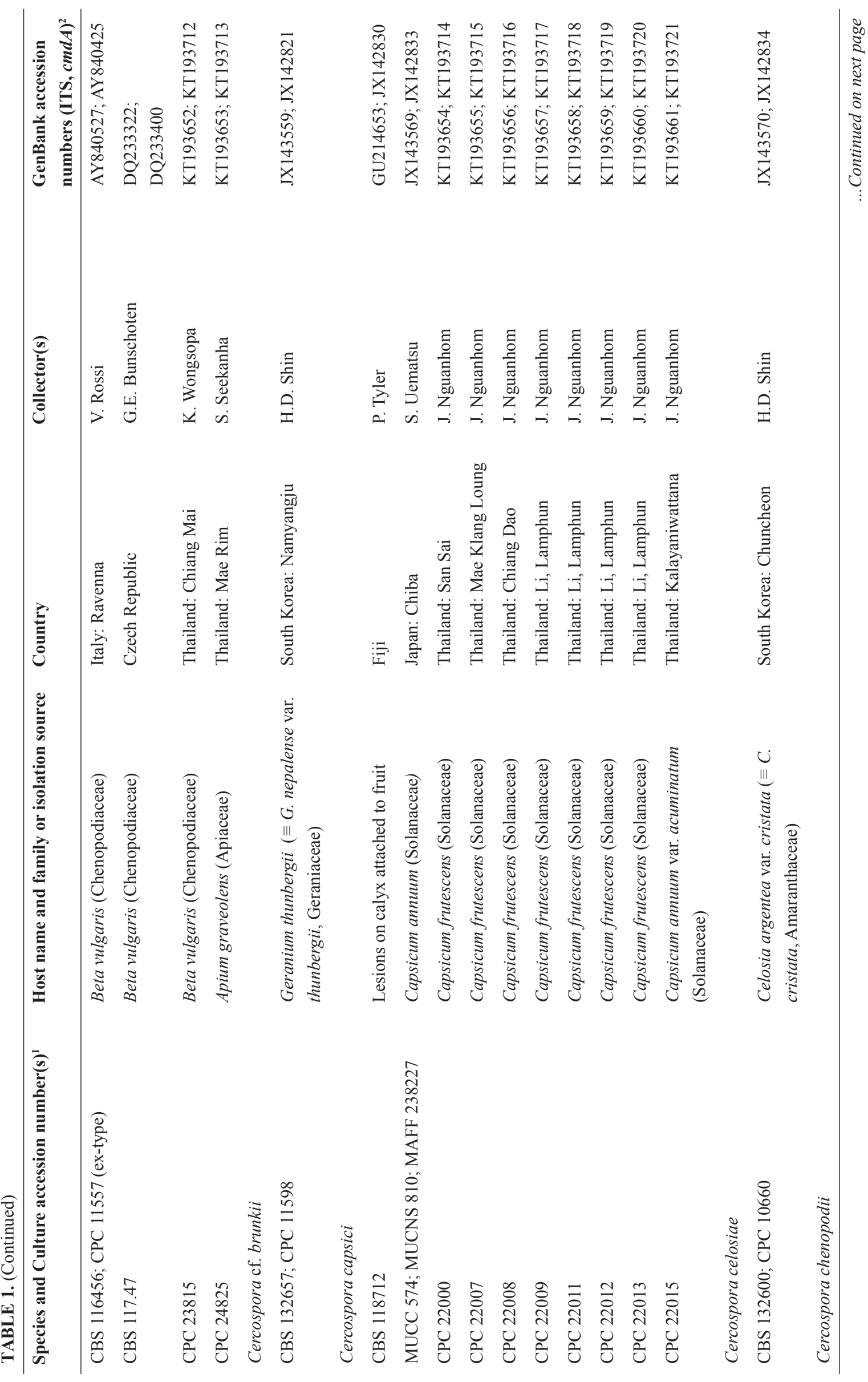




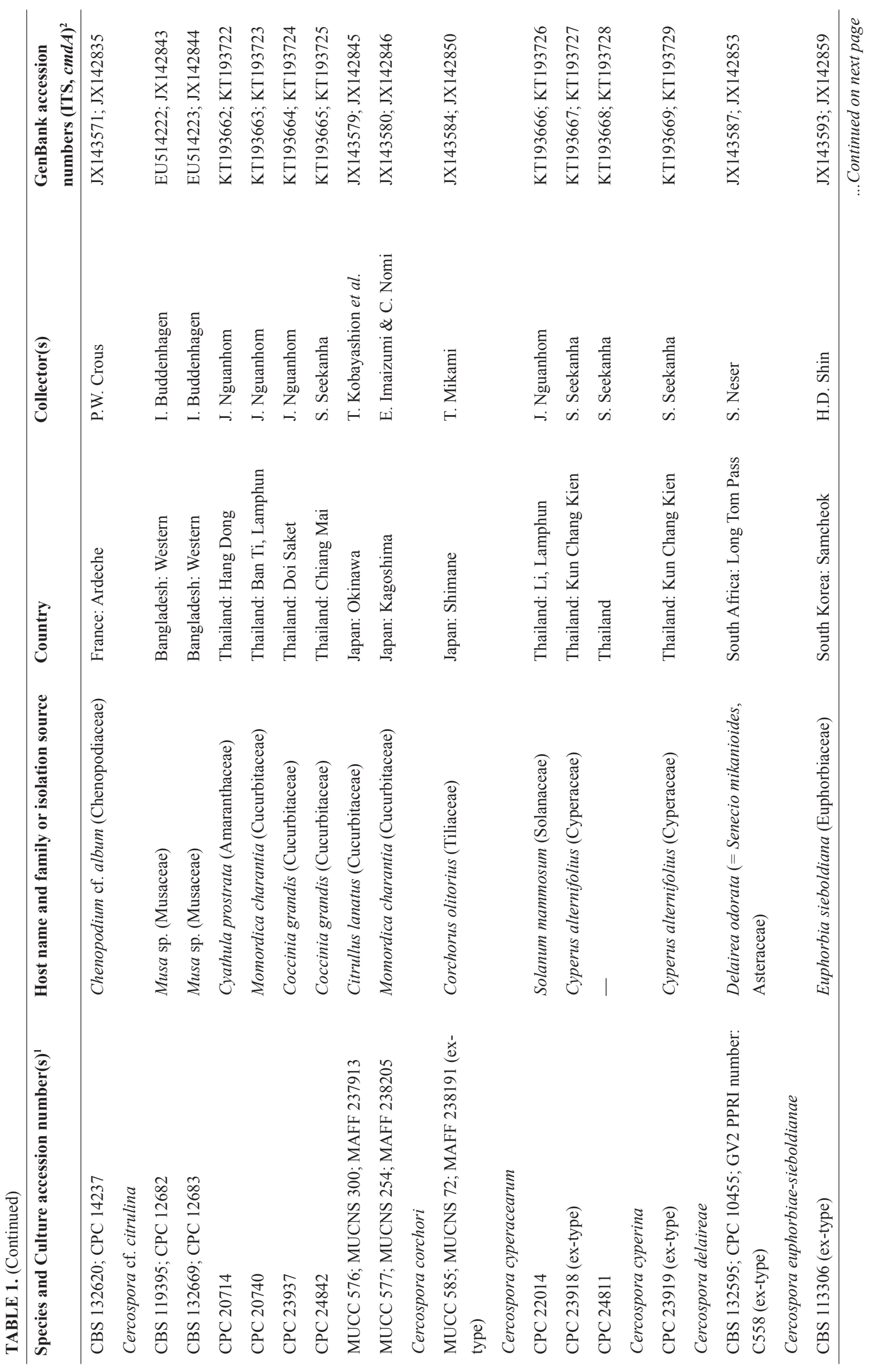




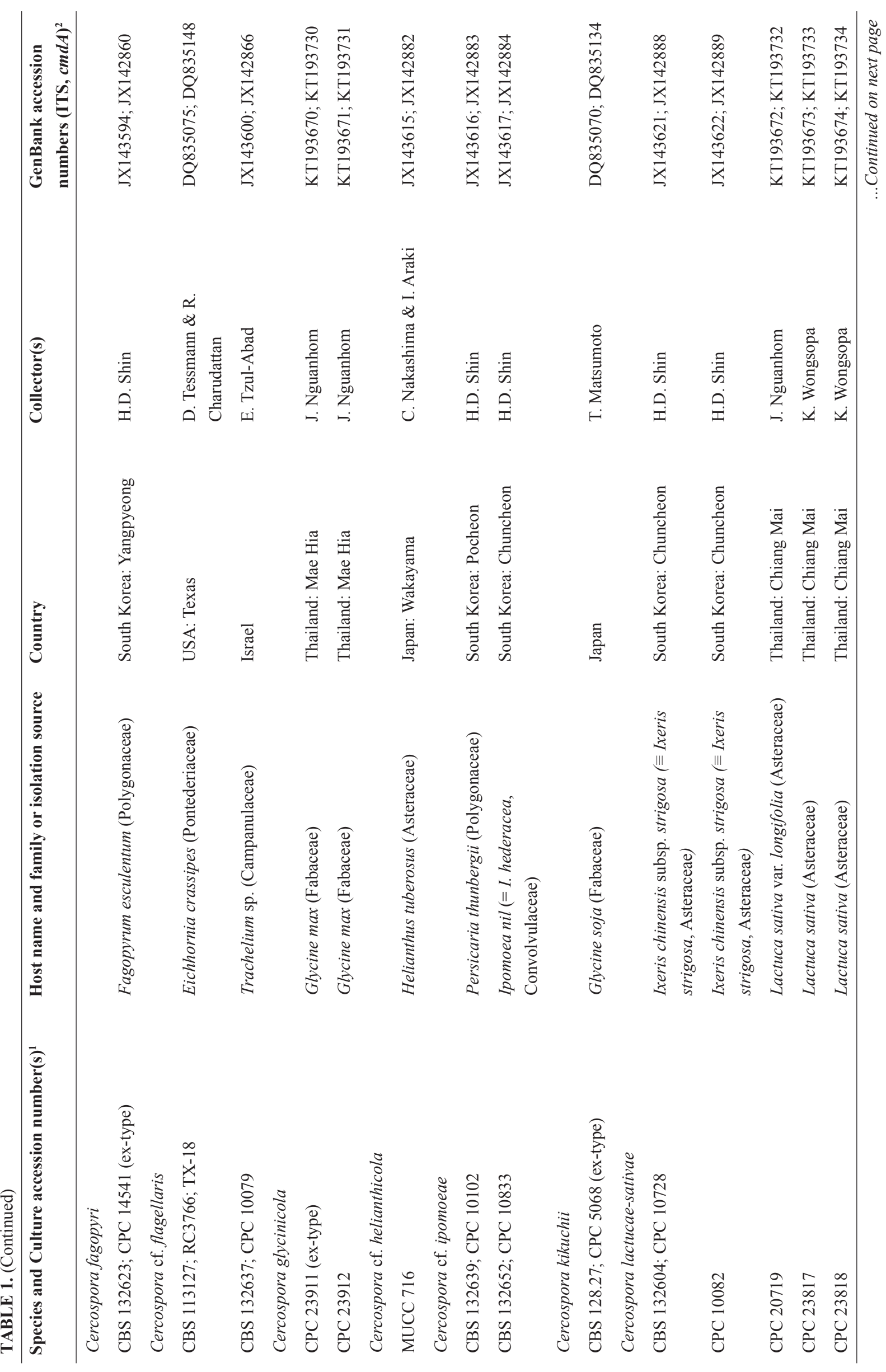




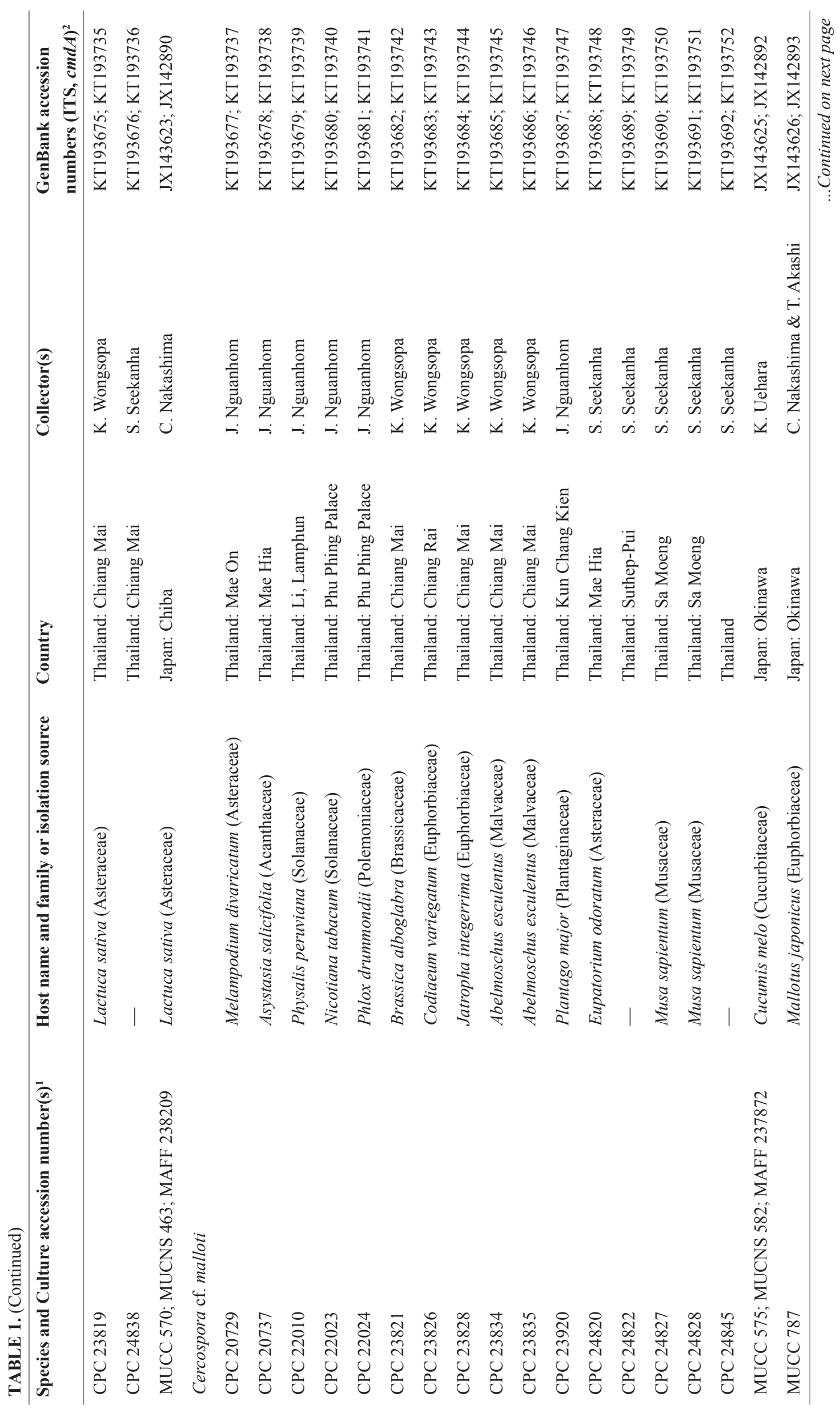




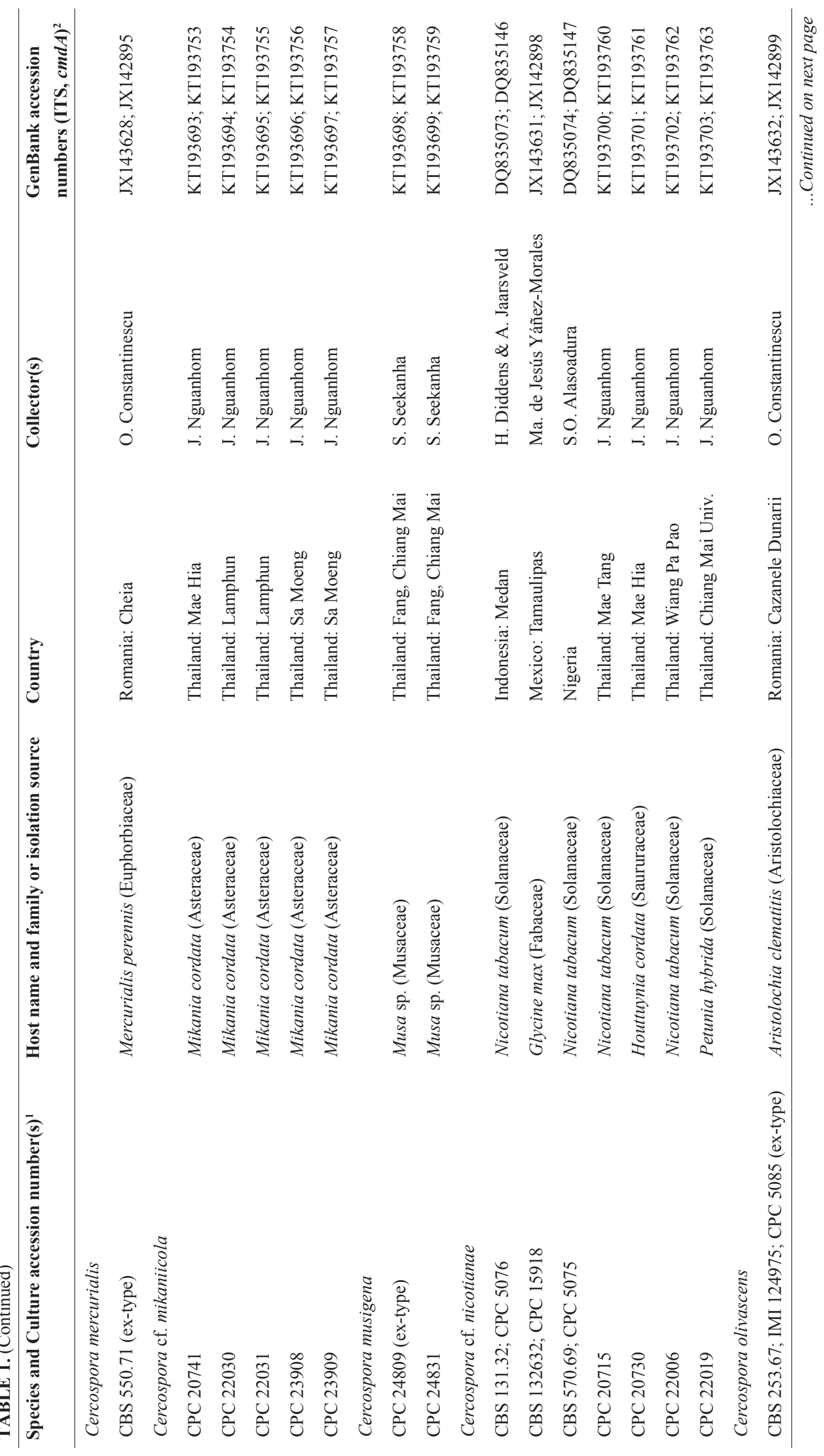




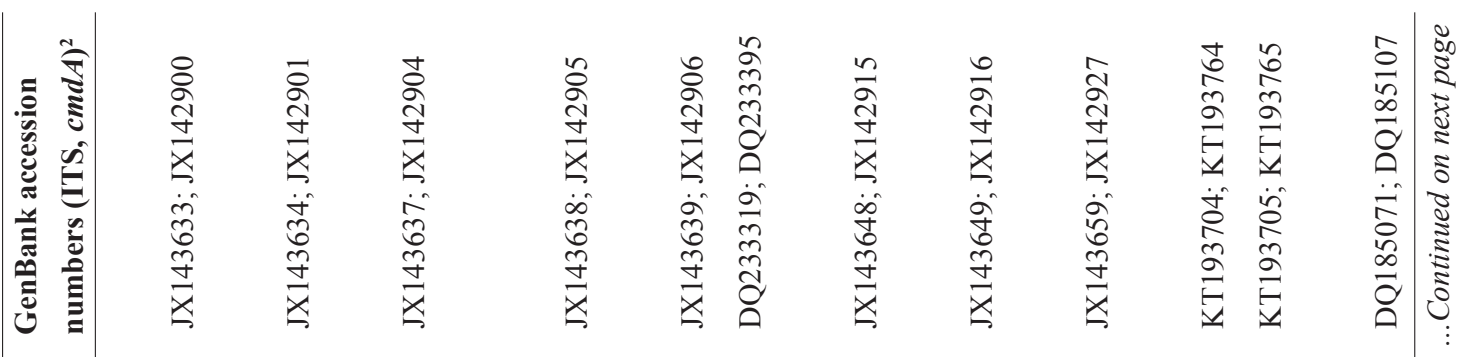

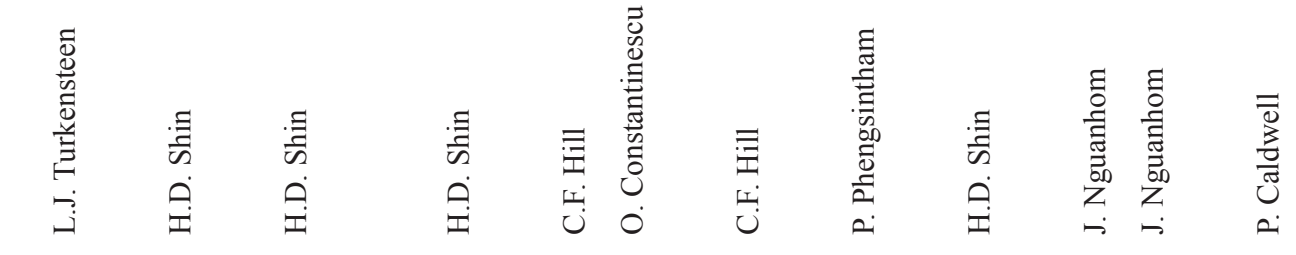

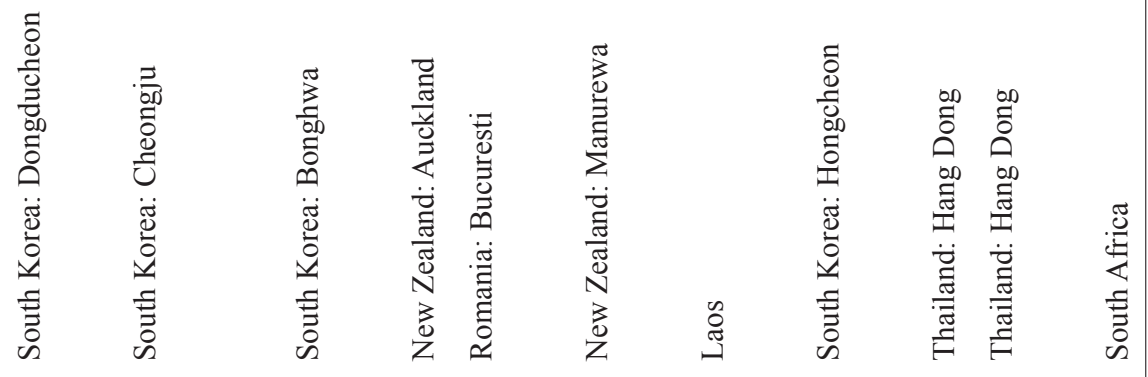

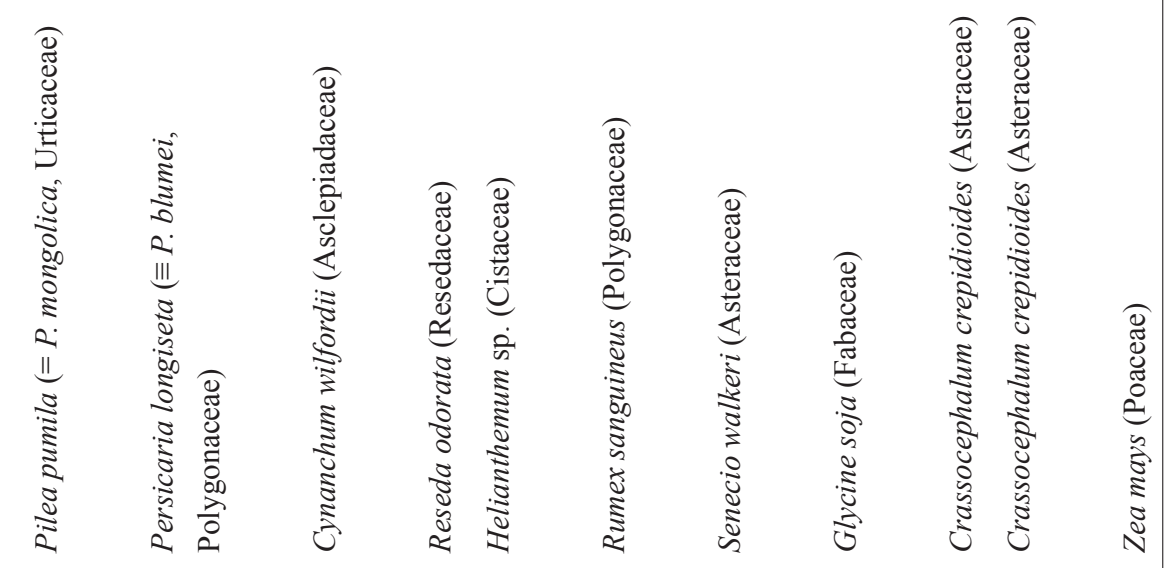

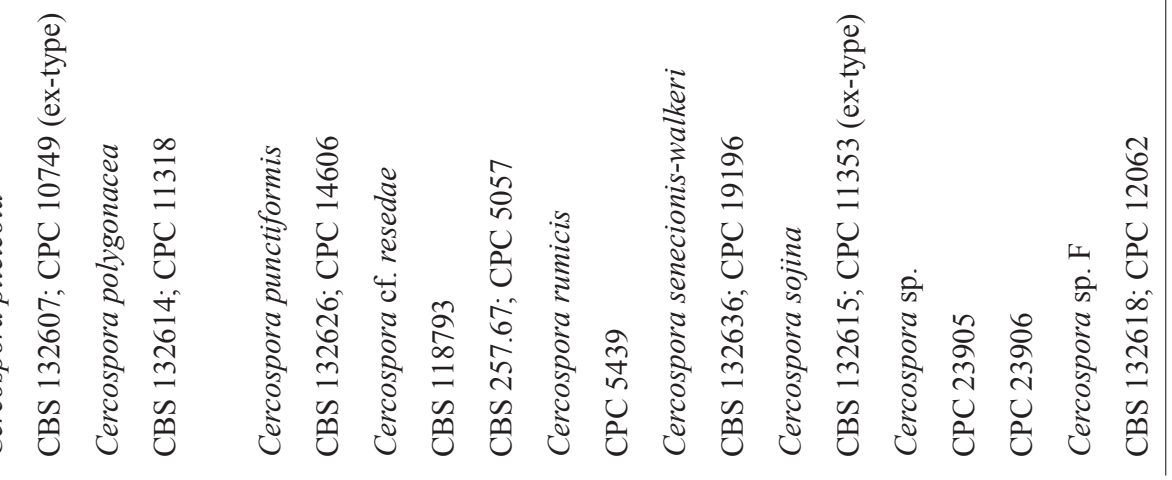




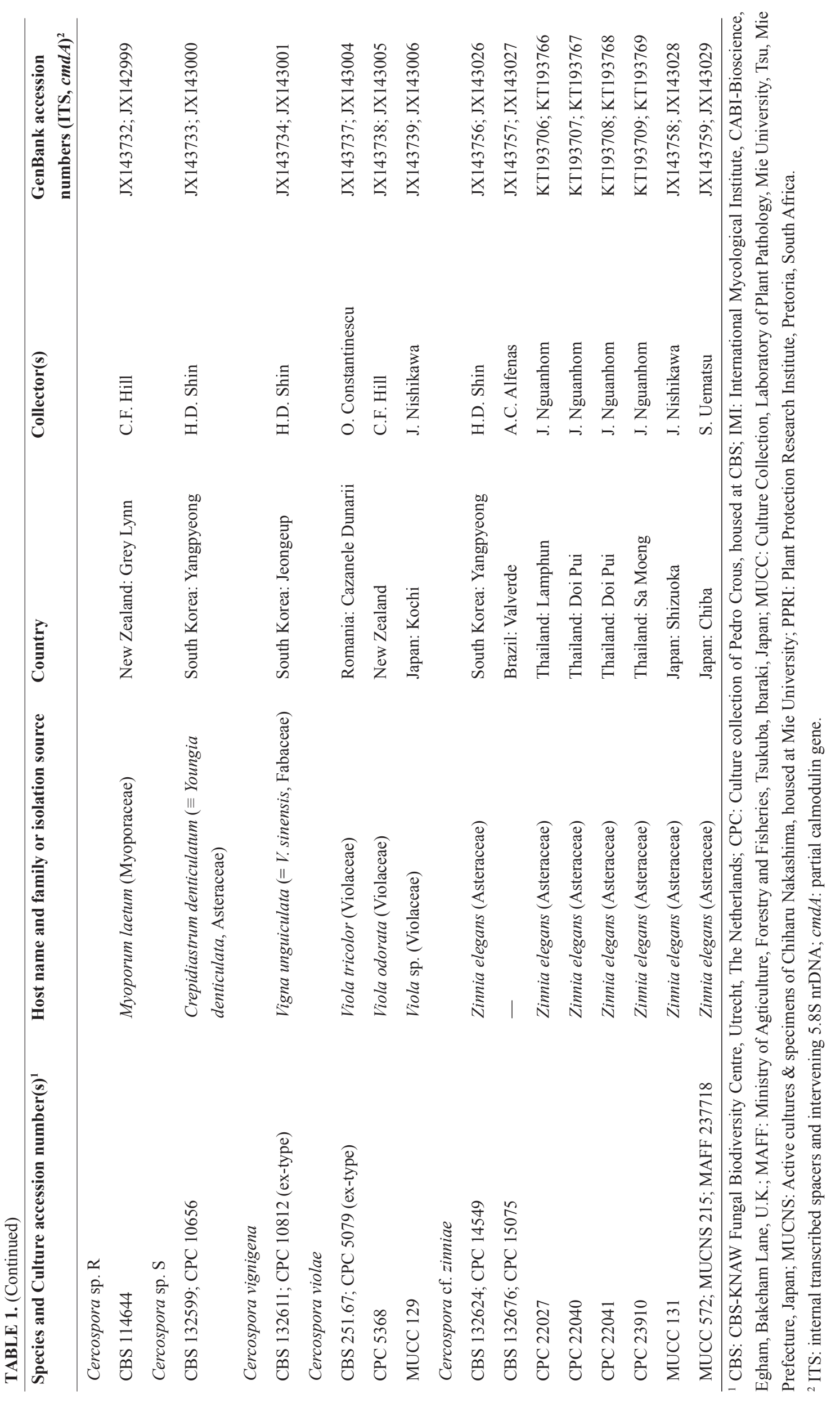




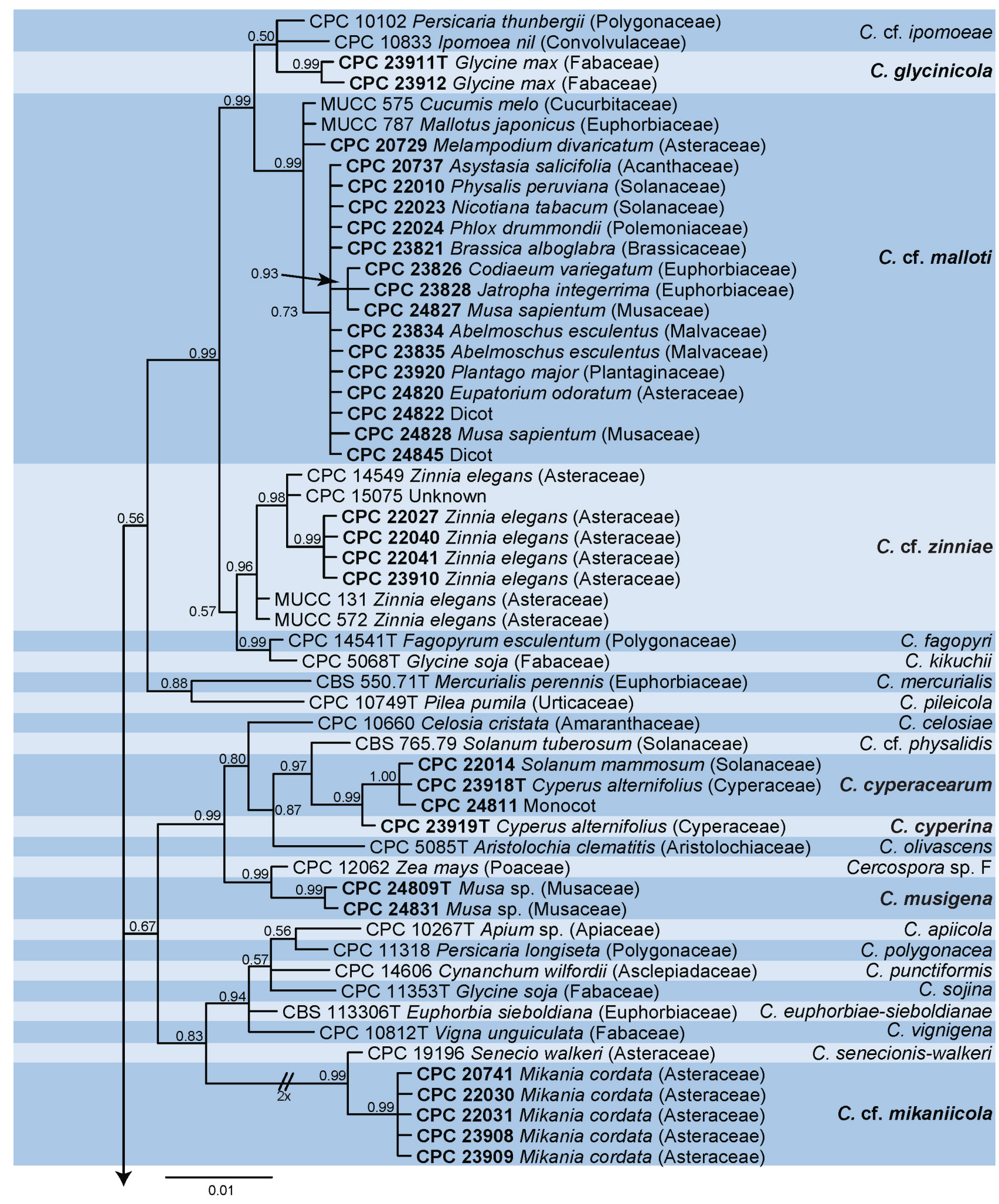

FIGURE 1. The Bayesian 50\% majority rule consensus tree derived from the combined ITS/cmdA alignment. Bayesian posterior probabilities support values for the respective nodes are displayed in the tree. The scale bar indicates 0.01 expected changes per site and species are delimited by blocks of different colours. Strain accession numbers from Thailand and names of species containing Thai strains are printed in bold face. The tree was rooted to Septoria provencialis CPC 12226 (ITS GenBank DQ303096, cmdA GenBank JX143030). 


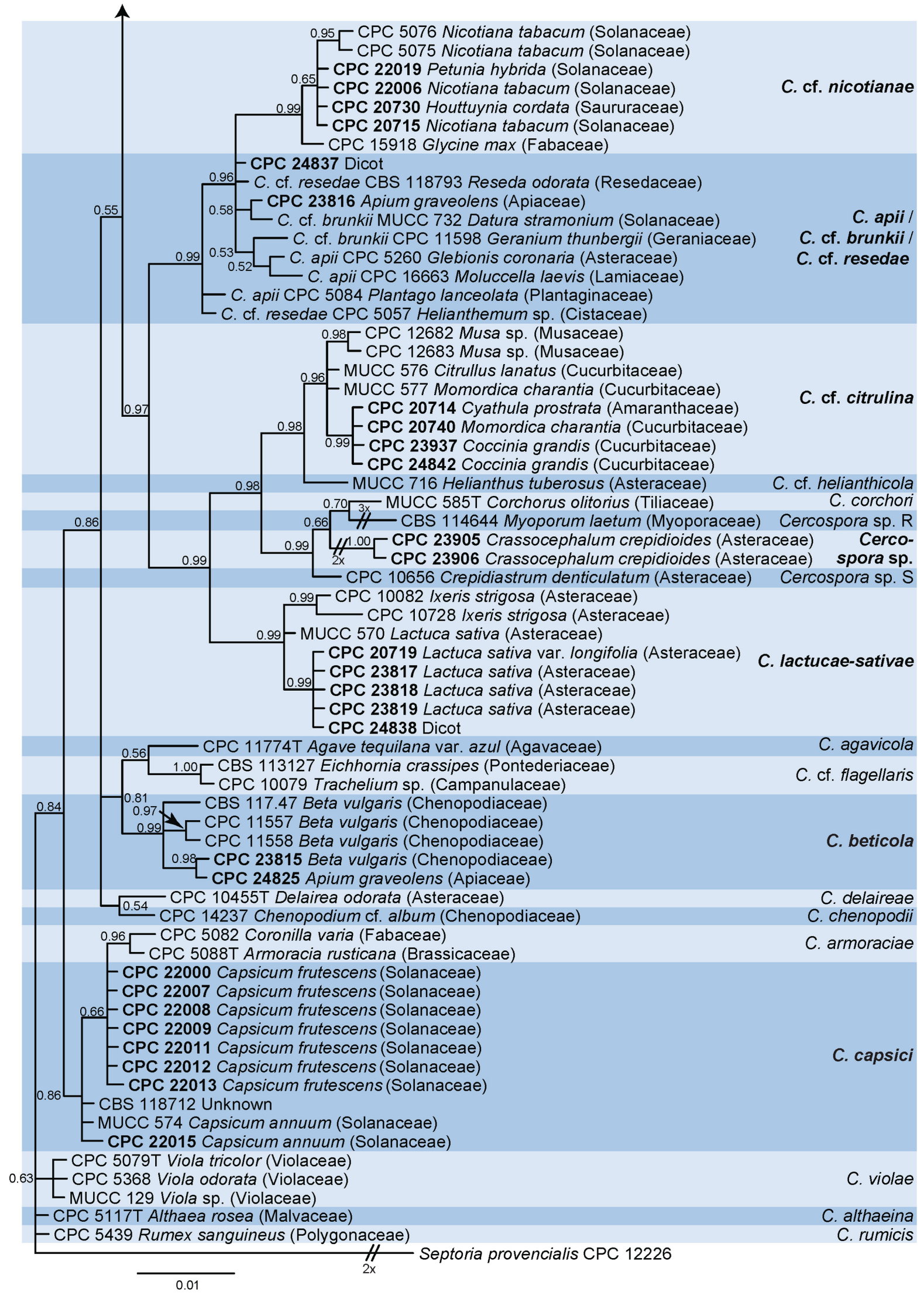

FIGURE 1. (Continued) The Bayesian 50\% majority rule consensus tree derived from the combined ITS/cmdA alignment. Bayesian posterior probabilities support values for the respective nodes are displayed in the tree. The scale bar indicates 0.01 expected changes per site and species are delimited by blocks of different colours. Strain accession numbers from Thailand and names of species containing Thai strains are printed in bold face. The tree was rooted to Septoria provencialis CPC 12226 (ITS GenBank DQ303096, cmdA GenBank JX143030). 


\section{Taxonomy}

Morphological descriptions of Cercospora spp. were based on structures from herbarium material. Fungal structures were mounted in lactic acid and examined using a Nikon Eclipse 80i compound microscope $(\times 1000)$, with 30 measurements taken for each structure, the $95 \%$ confidence intervals were determined, and extreme values given in parentheses. Colony colours on MEA, potato dextrose agar (PDA) and oatmeal agar (OA) (recipes according to Crous et al. 2009) were determined after $2 \mathrm{wk}$ at $25^{\circ} \mathrm{C}$ in the dark in duplicate. The mycological colour charts of Rayner (1970) were used to define colours of the fungal colonies. Nomenclatural novelties and descriptions were deposited in MycoBank (www. MycoBank.org; Crous et al. 2004). The naming system employed by Groenewald et al. (2013) was used to simplify comparison between the studies.

\section{Results}

\section{Phylogenetic analysis}

DNA data from the ITS and $\mathrm{cmdA}$ regions were combined in a MrBayes analysis. The sequence alignment consisted of 121 ingroup sequences and Septoria provencialis (CPC 12226) was used as outgroup. A combined dataset of a total of 731 characters was used in the phylogenetic analysis (470 and 261 characters for ITS and $c m d A$, respectively). Based on MrModeltest, a MrBayes analysis was conducted on the combined dataset using a symmetrical model (SYM) substitution model with equal rates. The dataset had fixed (equal) base frequencies implemented for ITS and had dirichlet base frequencies with gamma rates implemented for $c m d A$ by using HKY $+\mathrm{G}$ model. A total of 731 characters were used for the Bayesian analysis; these contained 156 and 171 unique site patterns for ITS and $c m d A$, respectively. A total of 5,168 trees were saved, of which the last 3,876 were used to calculate the tree presented in Fig. 1.

\section{Taxonomy}

Several taxa collected in the present study were found to be morphologically and phylogenetically distinct from presently known species. The phylogenetic analyses based on the Bayesian analysis resolved a total of 15 Cercospora lineages from Thailand, with two clades representing undefined Cercospora species complexes (sensu Groenewald et al. 2013). The species representing novel taxa are treated below.

\section{Cercospora glycinicola Cheew., Crous \& U. Braun, sp. nov. (Fig. 2). MycoBank MB812918}

Type:-THAILAND. Chiang Mai: on Glycine max (Fabaceae), 29 Mar. 2013, S. Seekanha (holotype CBS H-22289, culture ex-type CPC $23911=$ CBS 140164, CPC 23912).

Leaf spots amphigenous, subcircular to irregular, pale brown, surrounded by a darker brown margin, 1-3 mm diam. Mycelium internal. Caespituli amphigenous, punctiform, brown. Stromata brown, intraepidermal or substomatal, 32.5-57.5 $\mu \mathrm{m}$ diam. Conidiophores in moderately dense fascicles (4-25), straight or sinuous to geniculate due to sympodial proliferation, unbranched, brown, paler toward the apex, 30-113 $\times 4-6 \mu \mathrm{m}, 1-4$-septate. Conidiogenous cells proliferating sympodially, integrated, terminal or conidiophores reduced to conidiogenous cells, $28-60 \mu \mathrm{m}$ long; conidiogenous loci conspicuous, apical and formed on shoulders caused by geniculation, lateral, multi-local, loci distinctly thickened, darkened, 3-4 $\mu \mathrm{m}$ diam. Conidia solitary, obclavate-cylindrical, hyaline, obtuse at the apex, truncate to slightly obconically truncate at the base, $1-3$-septate, $23-83 \times 3-5 \mu \mathrm{m}$; hila thickened and darkened, $2.5-3$ $\mu \mathrm{m}$ diam.

Culture characteristics:- Colonies spreading, with moderate to dense, felty aerial mycelium, entire to undulate margin, reaching $42 \mathrm{~mm}$ diam after 2 wk. On MEA white, with somewhat greyish pink exudates. On PDA white to slightly grey, with diffuse red pigment in agar surrounding colony. On OA white to slightly grey, with diffuse red pigment in agar.

Etymology:- Named after its Glycine-inhabiting habit.

Notes:-Cercospora glycinicola is morphologically close to C. sojina (Shin \& Kim 2001) but distinct in having shorter conidiophores $(30-113 \mu \mathrm{m}$, versus $40-200 \mu \mathrm{m})$ and above all narrower conidia with few septa (3-5 $\mu \mathrm{m}$ wide, 1-3-septate, versus 4-8 $\mu \mathrm{m}$ wide, 3-7-septate). Phylogenetically it is also distinct from species presently known from DNA sequence data, including C. sojina. However, although these two isolates originate from the same lesion, they were morphologically different. Isolate CPC 23911 had more geniculate conidiophores, shorter conidiogenous cells 
(28-38 $\mu \mathrm{m})$ and slightly shorter conidia $(23-68 \mu \mathrm{m})$. In contrast, isolate CPC 23912 had straight conidiophores, longer conidiogenous cells $(45-60 \mu \mathrm{m})$ and somewhat acicular conidia. However, phylogenetically the two isolates only differed via one nucleotide position in $c m d A$.
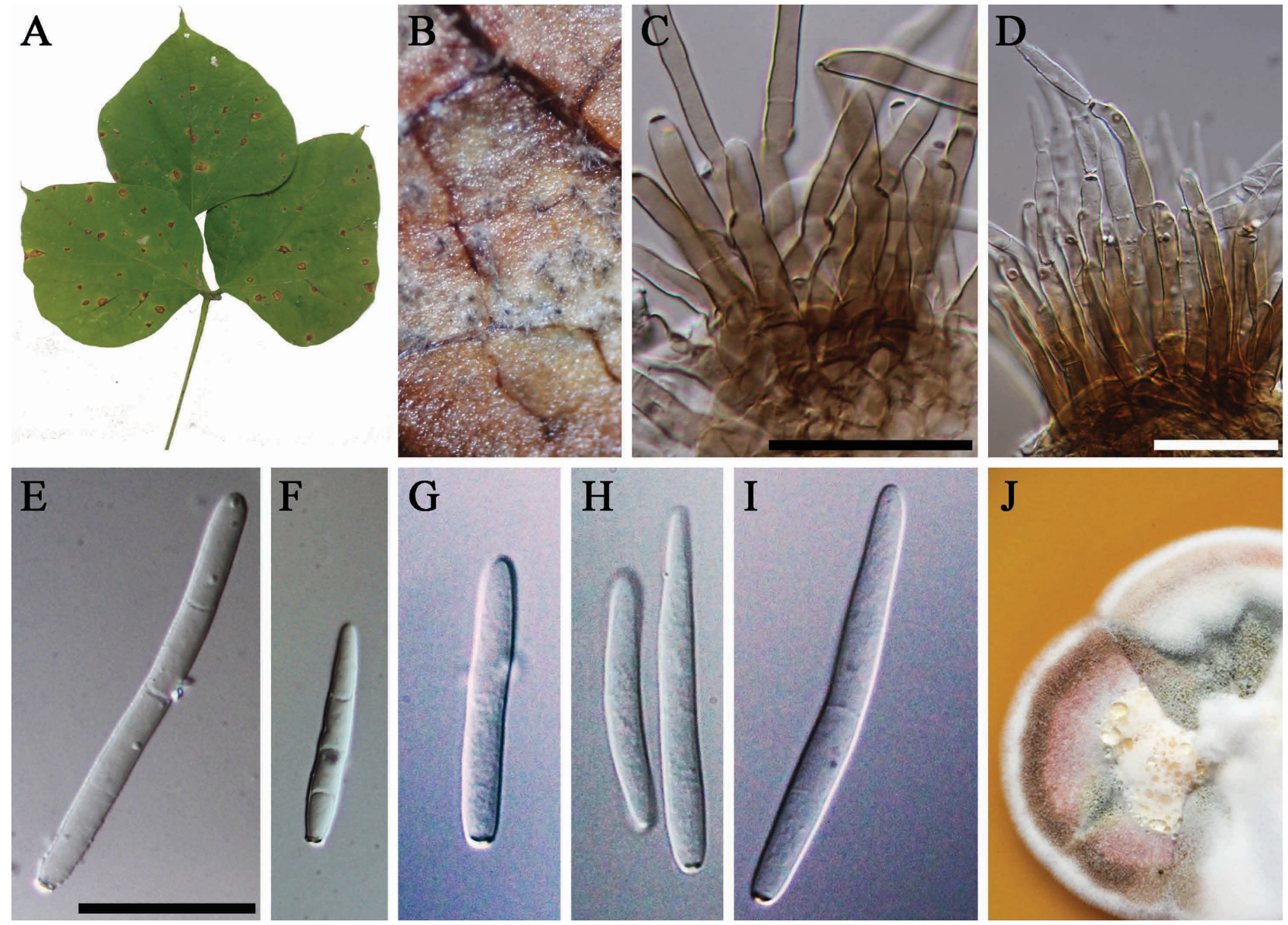

FIGURE 2. Cercospora glycinicola (CBS H-22289). A. Leaf spot; B. Close-up of leaf spot; C, D. Conidiophores and conidiogenous cells; E-I. Conidia; J. Colony on MEA.-Scale bars: C-D $=40 \mu \mathrm{m}$; $\mathrm{E}-\mathrm{I}=50 \mu \mathrm{m}$.

Cercospora cyperacearum Cheew., Crous \& U. Braun, sp. nov. (Fig. 3). MycoBank MB812919

Type:-THAILAND. Chiang Mai: on leaves of Cyperus alternifolius (Cyperaceae), 12 May 2013, S. Seekanha (holotype CBS H-22290, culture ex-type CPC $23918=$ CBS 140165).

Other specimens examined:- THAILAND. Chiang Mai: on unknown monocot, 12 May 2013, S. Seekanha, CPC 24811; Lamphun on leaves of Solanum mammosum (Solanaceae), 9 Dec. 2010, J. Nguanhom, CPC 22014.

Leaf spots amphigenous, pale brown to brown, margin indefinite, elongated to irregular. Caespituli amphigenous, punctiform, brown. Stromata substomatal to intraepidermal, brown, 38-63 $\mu \mathrm{m}$ high, 18-38 $\mu \mathrm{m}$ wide. Conidiophores fasciculate, pale olivaceous, paler and narrower towards the apex, unbranched, main portion straight, subcylindrical, only conidiogenous cells distinctly geniculate, $18-68 \times 4-5 \mu \mathrm{m}$. Conidiogenous cells proliferating sympodially 5-9 times, integrated, terminal, 18-35 $\mu \mathrm{m}$ long, conidiogenous loci conspicuous, thickened and darkened, apical and lateral, circumspersed, 1-3 $\mu \mathrm{m}$ diam. Conidia solitary, hyaline, thin-walled, smooth, obclavate-cylindrical, subacute to acute at the apex, truncate at the base, $40-63 \times 2-2.5 \mu \mathrm{m}$, indistinctly 1-6-septate, hila slightly thickened, darkened and refractive, $1-3 \mu \mathrm{m}$ diam.

Culture characteristics:-Colonies spreading, with dense aerial mycelium, reaching $40 \mathrm{~mm}$ diam after 2 wk. On MEA surface green-glaucous with pink pigment surrounding colony with undulate margins; reverse fucous-black. On PDA surface smoke grey with pink at the margin, entire margin; reverse fucous-black. On OA surface dense mycelium, with sparse entire margin, pure olivaceous-grey with diffuse livid red pigment surrounding colony; reverse dark vinaceous with lavender grey at the centre.

Etymology:-Epithet derived from the host genus, Cyperus. 

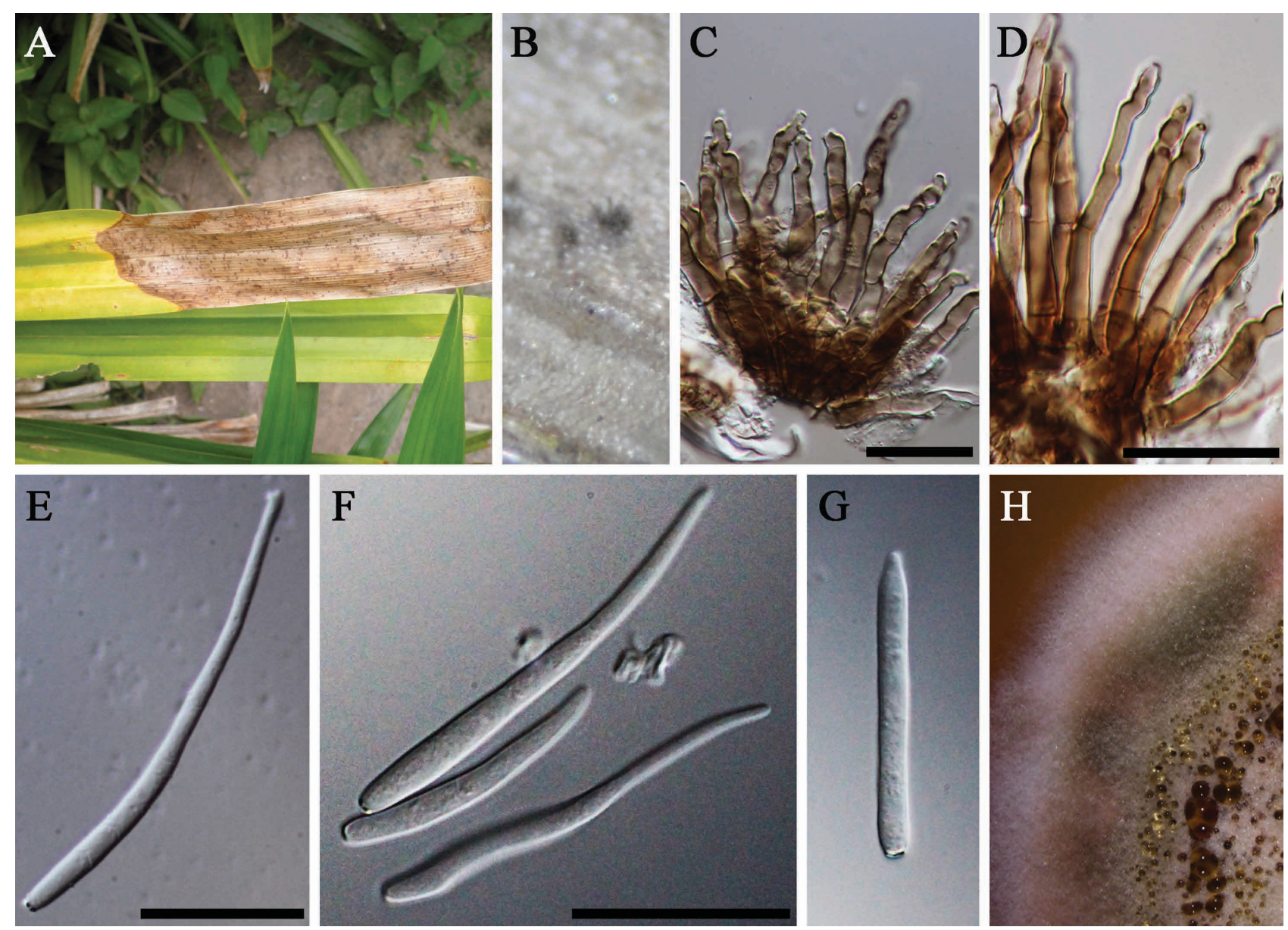

FIGURE 3. Cercospora cyperacearum (CBS H-22290). A. Leaf spot; B. Close-up of leaf spot; C, D. Conidiophores and conidiogenous cells; E-G. Conidia; H. Colony on MEA.-Scale bars: $\mathrm{C}-\mathrm{G}=40 \mu \mathrm{m}$.

Notes:-Cercospora cyperacearum is undoubtedly plurivorous, as it is known from DNA sequences retrieved from unrelated hosts, including dicots and monocots, rendering a final conclusion impossible. The occurrence on additional hosts cannot be excluded and is probable, i.e., previously described Cercospora species might be involved. The Cercospora species described from Cyperus spp. are morphologically distinct (Braun et al. 2014). Cercospora cyperigena $\mathrm{U}$. Braun \& Crous has much shorter, 0-1-septate conidiophores, 5-20 $\times 2-5 \mu \mathrm{m}$, and C. cyperi Sawada has small stromata, 10-25 $\mu \mathrm{m}$ diam, smaller conidiogenous loci, (1-)1.5-2(-2.5) $\mu \mathrm{m}$ diam, and broader conidia, (2-)2.55(-5.5) $\mu \mathrm{m}$ (Braun et al. 2014). Cercospora cyperacearum on Cyperus alternifolius in Thailand is characterised by forming large stromata and narrow conidia, and agrees well with the description of Cercospora ugandensis in Vasudeva (1963) based on Indian material on Cyperus sp., which is, however, not in agreement with the original description of this species that has been reduced to synonymy with C. cyperi in Braun et al. (2014). The characters of conidiophores and conidia of Cercospora spp. on Solanum are not in agreement with the material on Solanum mammosum. $C$. solanicola and C. melongenae are C. apii-like, i.e., with consistently acicular conidia, and were reduced to synonymy with C. physalidis s. lat. in Braun \& Mel'nik (1997), which was considered to be part of the C. apii s. lat. complex in Crous \& Braun (2003). These species are characterised by having long, pluriseptate conidiophores to $200 \mu \mathrm{m}$, and conidia to $300 \times 2.5-5 \mu \mathrm{m}$. The conidiophores in $C$. solani agree well with those of $C$. cyperacearum but the lesions are indistinct and the acicular conidia are 3.5-6 $\mu \mathrm{m}$ wide (Chupp 1954; type material examined: Thüm., Mycoth. univ. 2070, HAL). C. solanigena (Bhartiya et al. 2000), described from India on Solanum melongena, resembles $C$. cyperacearum. However, the stromata are smaller, 10-30 $\mu \mathrm{m}$ diam, and the conidiophores are 16-100 $\times 3-5 \mu \mathrm{m}$, 1-6-septate, with conidia being cylindrical-obclavate to acicular (based on the original illustrations), $15-85 \times 2-5 \mu \mathrm{m}$, $1-5$-septate. 
Type:-THAILAND. Chiang Mai: on leaves of Cyperus alternifolius (Cyperaceae), 12 May 2013, S. Seekanha (holotype CBS H-22291, culture ex-type CPC $23919=$ CBS 140166).
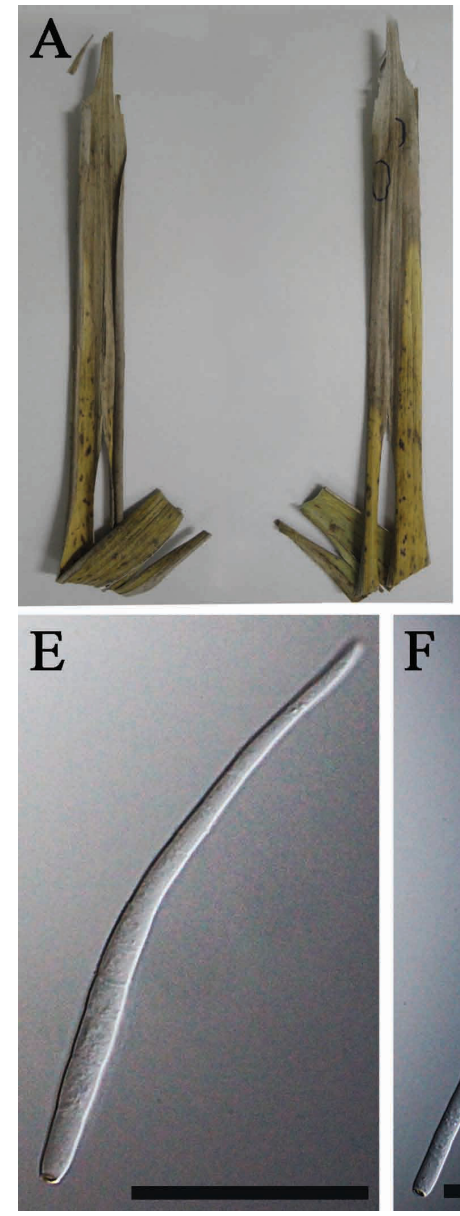
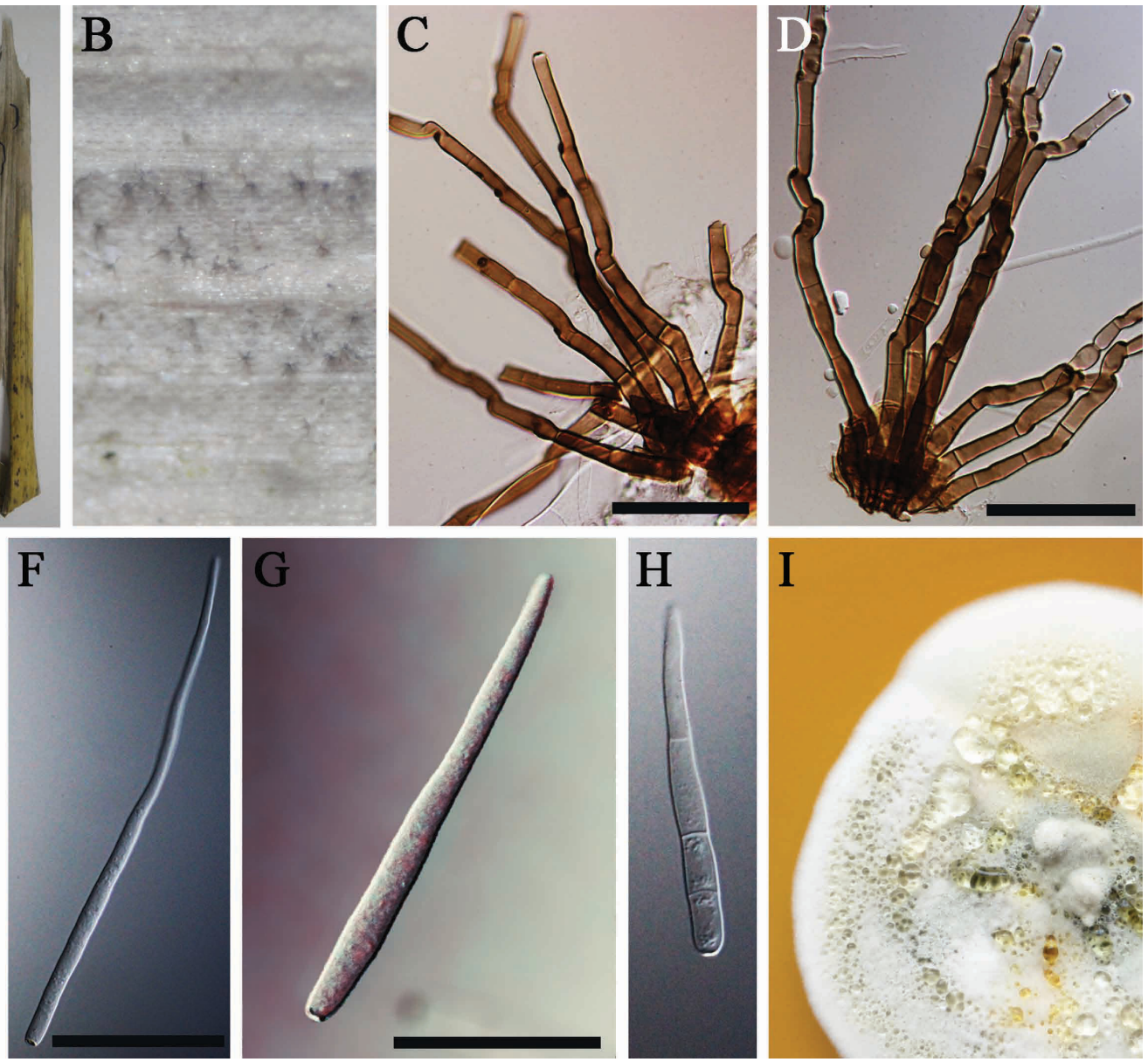

FIGURE 4. Cercospora cyperina (CBS H-22291). A. Leaf spot; B. Close-up of leaf spot; C, D. Conidiophores and conidiogenous cells; E-H. Conidia; I. Colony on MEA.-Scale bars: $\mathrm{C}-\mathrm{D}=40 \mu \mathrm{m}$; $\mathrm{E}-\mathrm{H}=50 \mu \mathrm{m}$, and $\mathrm{G}$ applies to $\mathrm{H}$.

Leaf spots amphigenous, pale brown to brown, margin indefinite, elongated to irregular. Mycelium internal. Caespituli amphigenous, punctiform, brown. Stromata none or composed of 2-3 brown cells. Conidiophores loosely fasciculate, with fascicles of 2-9 conidiophores, brown, paler towards the apex, cylindrical to geniculate, somewhat constricted at septa, branched, 2-6-septate, 73-138 $\times 5-6 \mu \mathrm{m}$. Conidiogenous cells proliferating sympodially 1-6 times, integrated, terminal and intercalary, 20-38 $\mu \mathrm{m}$ long; conidiogenous loci conspicuous, thickened and darkened, multi-local, formed apical or on shoulders caused by proliferation, 2.5-4 $\mu \mathrm{m}$ diam. Conidia solitary, hyaline, thin-walled, smooth, acicular to somewhat obclavate, subobtuse at the apex, truncate to slightly obconically truncate at the base, 55-155 $\times 2.5-4$ $\mu \mathrm{m}$, indistinctly 15-20-septate, hila slightly thickened, darkened and refractive, 2.5-3 $\mu \mathrm{m}$ diam.

Culture characteristics:-Colonies spreading, low convex, with sparse to moderate aerial mycelium, entire margin and folded surface, reaching $44 \mathrm{~mm}$ diam after $2 \mathrm{wk}$. On MEA surface whitish with patches of greyish rose; reverse olivaceous-black. On PDA surface whitish, pale grey at the centre with diffuse red pigment surrounding the colony; reverse olivaceous-black. On OA whitish with patches of pale grey, but red at the margin; reverse olivaceousgrey.

Etymology:-Epithet derived from the host genus, Cyperus.

Notes:-Cercospora cyperina is morphologically close to C. cyperi Sawada (Braun et al. 2014) but distinct by having longer, distinctly geniculate conidiophores with constrictions and much larger conidiogenous loci, 3-4 $\mu \mathrm{m}$ diam [conidiophores (10-)20-90 $\mu \mathrm{m}$ long, without constrictions, loci (1-)1.5-2(-2.5) $\mu \mathrm{m}$ diam in C. cyperi]. This taxon was also supported as a new species based on its distinct phylogenetic position. In the combined tree (Fig. 1), it is sister to C. cyperacearum and thus separate from other species occurring on Cyperus. 
Cercospora musigena Nguanhom, Crous \& U. Braun, sp. nov. (Fig. 5). MycoBank MB812921

Type:-THAILAND. Chiang Mai: on leaves of Musa sp. (Musaceae), 27 May 2013, S. Seekanha (holotype CBS H-22292, culture ex-type CPC 24809 = CBS 140167, CPC 24831).
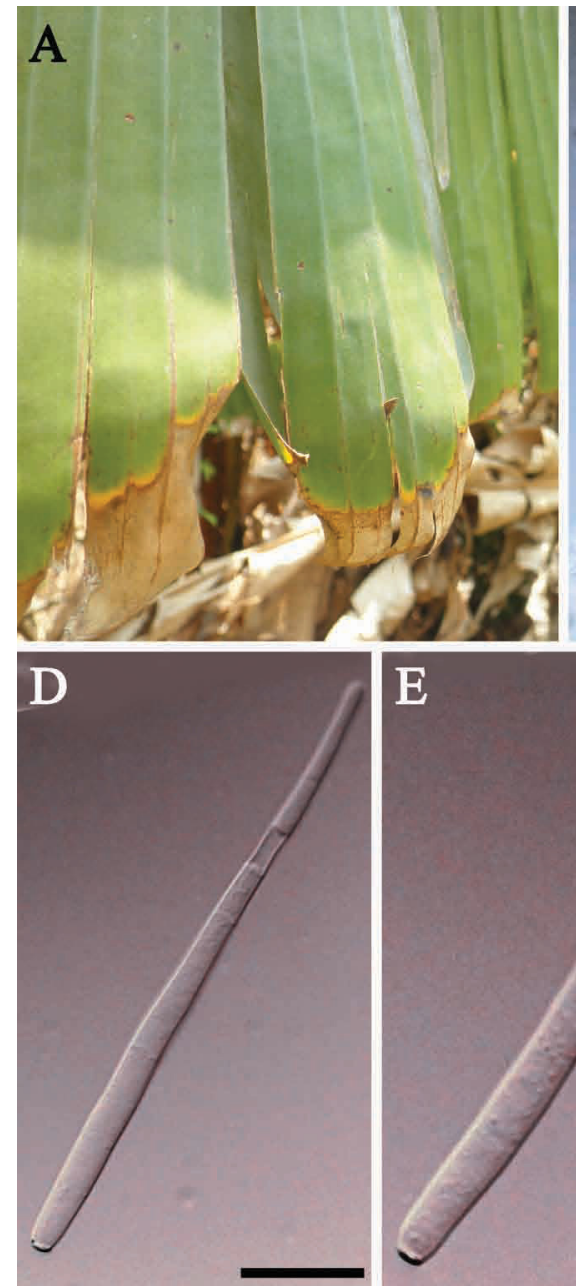

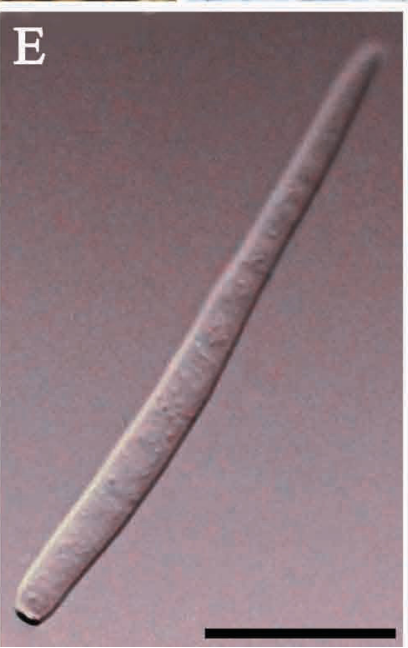

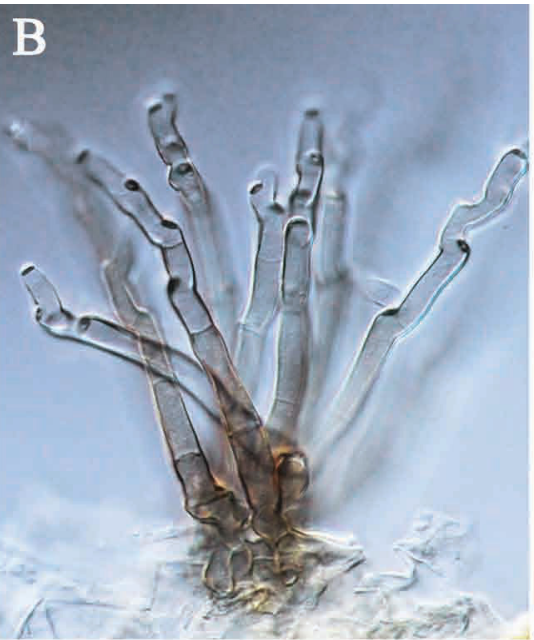
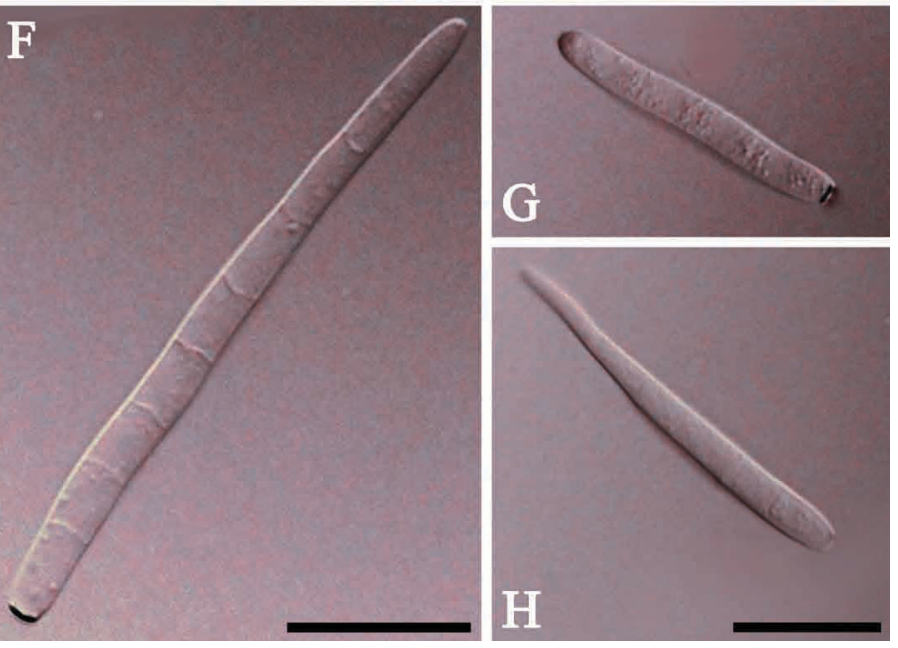

FIGURE 5. Cercospora musigena (CBS H-22292). A. Leaf spot; B, C. Conidiophores and conidiogenous cells; D-H. Conidia.- Scale bars: $\mathrm{B}-\mathrm{C}=50 \mu \mathrm{m} ; \mathrm{D}-\mathrm{H}=30 \mu \mathrm{m}$.

Leaf spots irregular, pale brown along the leaf margins, often surrounded by a yellow halo. Caespituli amphigenous, punctiform, brown. Stromata intraepidermal to subepidermal, brown, 30-45 $\mu \mathrm{m}$ diam. Conidiophores in moderately large fascicles (11-20 per fascicle), erumpent through the cuticle, brown, paler toward the apex, 3-5-septate, cylindrical, 1-3 times geniculate in upper part, tapering to flat-tipped loci, branched, $30-75 \times 4-5 \mu \mathrm{m}$. Conidiogenous cells proliferating sympodially 1-4 times, integrated, terminal, rarely intercalary; conidiogenous loci distinct, apical or formed on shoulders due to sympodial proliferation, thickened and darkened, protruding, 2-3 $\mu \mathrm{m}$ diam. Conidia solitary, hyaline, straight to mildly curved, acicular, truncate at the base, obtuse at the apex, thin-walled, smooth, 15-130 × 3-5 $\mu \mathrm{m}, 2-20$-septate, hila thickened, darkened, 2-2.5 $\mu \mathrm{m}$ diam.

Culture characteristics:- Colonies spreading, flat, with sparse to dense aerial mycelium, even margin, reaching $48 \mathrm{~mm}$ diam after $2 \mathrm{wk}$. On MEA surface pale purplish grey, with rosy buff outer region; reverse sepia. On PDA surface vinaceous-buff, with red diffuse pigment surrounding culture; reverse bay. On OA surface whitish, with patches of grey; reverse chestnut, with rust in outer region.

Etymology:- Named after the host from which it was isolated, Musa sp.

Notes:-Cercospora musigena is similar to C. hayi Calp. by its acicular conidia with truncate bases, being part of the C. apii complex (Braun et al. 2014). In C. hayi, however, there are fewer conidiogenous loci per conidiogenous cell, and the conidial tips are acute to subacute (Calpouzos 1955). C. apii s. lat. (including C. hayi) on Musa spp. is genetically heterogeneous. Sequences retrieved from C. apii-like cultures isolated from banana clustered in three 
different clades (Groenewald et al. 2013). However, the identity of the name C. hayi is still unresolved and will need to be clarified by means of epitypification (Braun et al. 2014).

Cercospora sp. (Fig. 6).

Specimen examined:- THAILAND. Chiang Mai: on leaves of Crassocephalum crepidioides (Asteraceae), 29 Mar. 2013, J. Nguanhom (specimen CBS H-22293, culture CPC 23905, CPC 23906 = CBS 140168).
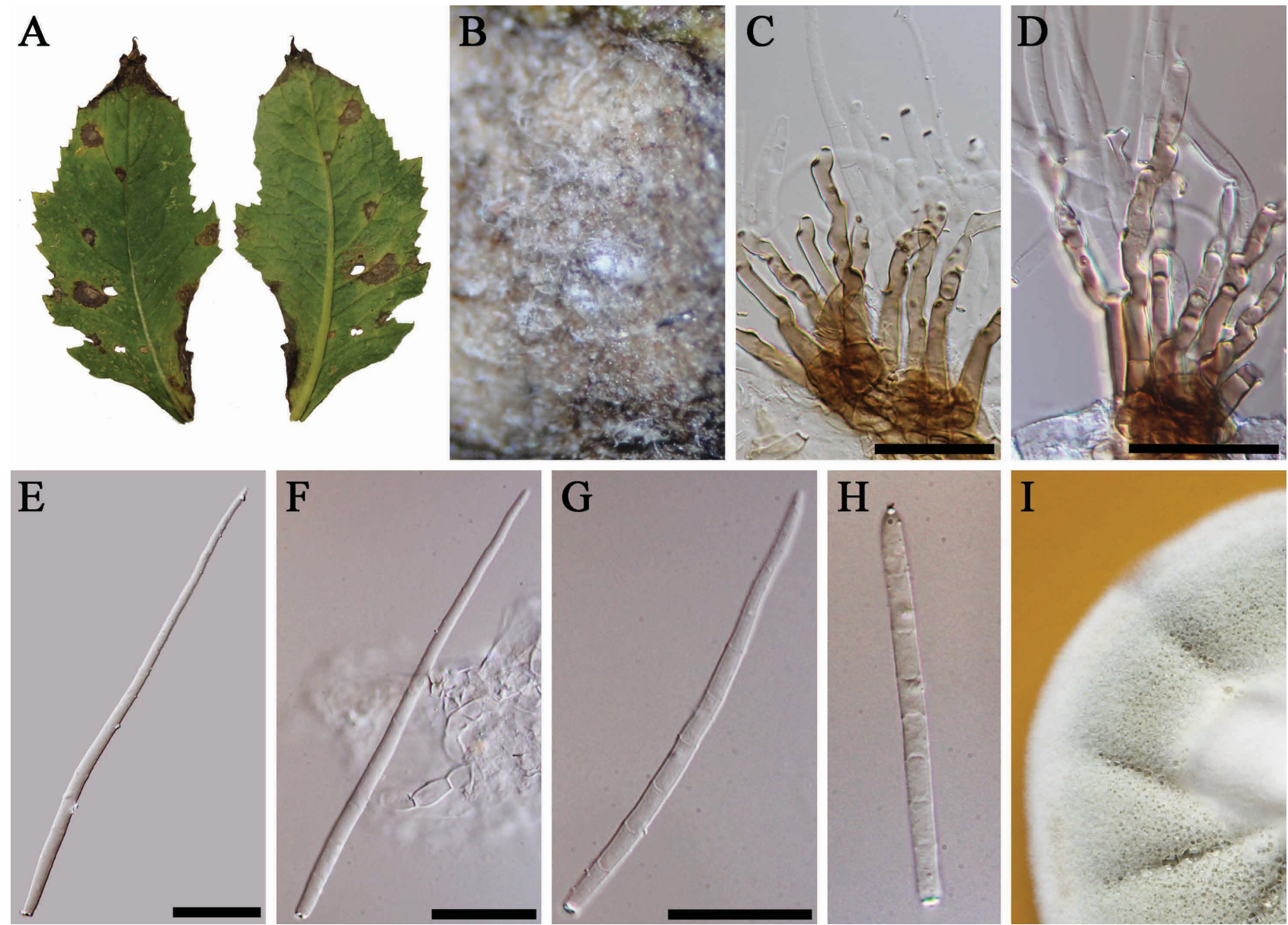

FIGURE 6. Cercospora sp. (CBS H-22293). A. Leaf spot; B. Close-up of leaf spot; C, D. Conidiophores and conidiogenous cells; E-H. Conidia; I = colony on MEA.-Scale bars: $\mathrm{C}-\mathrm{D}=40 \mu \mathrm{m}$; $\mathrm{E}-\mathrm{H}=50 \mu \mathrm{m}, \mathrm{G}$ applies to $\mathrm{H}$.

Leaf spots amphigenous, circular to irregular, dark brown with pale brown centre, 3-5 mm diam. Caespituli amphigenous, punctiform, brown. Stromata medium in size, substomatal or intraepidermal, brown, 27.5-37.5 $\mu \mathrm{m}$ diam. Conidiophores in moderately large fascicles, arising from stromata, through stomata or erumpent, cylindrical to strongly geniculate, brown, paler towards the apex, unbranched, rarely constricted near the apex, 50-133 $\times 5-6 \mu \mathrm{m}$. Conidiogenous cells proliferating sympodially $2-12$ times, integrated, terminal, 20-75 $\mu \mathrm{m}$ long; loci conspicuous, apical or on shoulders formed by geniculation, thickened and darkened, 2-3 $\mu \mathrm{m}$ diam. Conidia solitary, acicular, shorter ones subcylindrical, hyaline, smooth, thin-walled, straight to curved, apices subacute to obtuse, base truncate, indistinctly 3-12-septate, $27.5-180 \times 2-5 \mu \mathrm{m}$, hila thickened and darkened, $2-3 \mu \mathrm{m}$ wide; microcyclic conidiation observed.

Culture characteristics:-Colonies spreading, flat, with sparse to moderate aerial mycelium, folded surface and even margins, reaching $45 \mathrm{~mm}$ after $2 \mathrm{wk}$. On MEA pale grey, with white centres, whitish at the margin; olivaceousgrey in reverse. On PDA whitish grey; reverse olivaceous-grey. On OA whitish grey (due to aerial mycelium); reverse blackish.

Notes:-The genus Crassicephalum is close to Senecio and allied genera and in subtribe Senecioninae in tribe Senecioneae. The cercosporoid fungus on Crassocephalum crepidioides is morphologically indistinguishable from Cercospora apii s. lat., by having acicular conidia with truncate bases. C. senecionis Ellis \& Everh. is morphologically very close, except for somewhat wider conidiophores, 4-8 $\mu \mathrm{m}$, and conidia, 3-6 $\mu \mathrm{m}$ (Braun \& Mel'nik 1997). $C$. 
senecionicola Davis differs in having uniformly short, non-geniculate conidiophores, $15-55 \times 4-5 \mu \mathrm{m}$, and acicular to obclavate conidia, 2-3.5 $\mu$ m wide (Chupp 1954). The Indian C. senecionis-grahamii Thirum. \& Govindu (Thirumalachar \& Govindu 1962) is morphologically barely distinguishable from material on Crassocephalum crepidioides. Erechtites is another genus belonging in subtribe Senecininae and confusable with Crassocephalum. C. erechtitis G.F. Atk. is a widespread species, also known from Asia (Hsieh \& Goh 1990), and is morphologically also similar to material on Crassocephalum, being C. apii-like in morphology. Sequence data of the species on hosts belonging to the Senecioninae, which are morphologically involved in this complex, are not yet available for comparison. Furthermore, Crassocephalum crepidioides is an African species not native in Thailand. Therefore, an infection of this host by another Cercospora species, native or exotic, cannot be excluded. Hence, the present data do not allow a final conclusion and taxonomic treatment of the Cercospora sp. occurring on Crassocephalum to be made until such time as the phylogeny of related taxa has been clarified.

\section{Discussion}

Approximately 500 cercosporoid species have been reported from Thailand, including 300 species of Cercospora. To date these taxa have primarily been identified based on their morphology, and only a few have been studied phylogenetically (To-anun et al. 2010, 2011). In several phylogenetic studies, multi-gene DNA sequence data have proven highly effective to distinguish among species of Cercospora (Groenewald et al. 2005, 2006a, b, 2010, 2013, Bakhshi et al. 2015a, b). The same approach was followed in this study, leading to the conclusion that morphological characters and molecular techniques are complementary, and both necessary to underpin novel species of Cercospora from Thailand. The results obtained here provide strong support for the distinction of several Cercospora species based on an analysis of ITS and $c m d A$ DNA sequence data.

Four new species of Cercospora were recognized in this study. Cercospora glycinicola is morphologically similar to C. sojina, which also occurs on Glycine max, but is distinct in that it has shorter conidiophores and narrower conidia. Two species were described from Cyperus, namely C. cyperacearum and C. cyperina. Based on a range of characters related to conidiophore length, septation, stromatal size, and conidium morphology, these species appear distinct from the taxa presently known to occur on Cyperus (Braun et al. 2014). However, Cercospora cyperacearum is plurivorous, and also occurs on Solanum mammosum, although it is morphologically distinct from the species known from Solanum (Braun \& Mel'nik 1997, Bhartiya et al. 2000, Crous \& Braun 2003). Further collections in the region are required to determine if $C$. cyperacearum could also be found on additional hosts, but ultimately cross-inoculation experiments would be required to determine if the different hosts are only chance occurrences, or if this is a truly plurivorous species.

Cercospora collections occurring on Musa have always been assigned to C. hayi, which was originally described from banana leaves collected in Cuba (Calpouzos 1955). However, in a recent phylogenetic study, Groenewald et al. (2013) showed that sequences retrieved from C. apii-like cultures isolated from banana leaves collected in different countries clustered in three different clades. It is therefore not surprising that the collection obtained from Thailand is distinct from these unnamed taxa, and from C. apii s. str. Unfortunately, the three taxa referred to by Groenewald et al. (2013) are sterile, and thus further collections would be called for to try and elucidate the Cercospora complex occurring on banana, which is a host that appears to harbour a range of unique cercosporoid fungi (Arzanlou et al. 2008).

In addition to these novel taxa, three Cercospora species were found on new hosts (based on the clades phylogenetically defined by Groenewald et al. 2013): C. cf. citrullina on Cyathula prostrata (Amaranthaceae); $C$. cf. mallotionAbelmoschus esculentus (Malvaceae),Asystasiasalicifolia(Acanthaceae),Brassicaalboglabra(Brassicaceae), Codiaeum variegatum (Euphorbiaceae), Eupatorium odoratum (Asteraceae), Jatropha integerrima (Euphorbiaceae), Melampodium divaricatum (Asteraceae), Musa sapientum (Musaceae), Nicotiana tabacum (Solanaceae), Phlox drummondii (Polemoniaceae), Physalis peruviana (Solanaceae), and Plantago major (Plantaginaceae); and C. cf. nicotianae on Houttuynia cordata (Saururaceae).

Results obtained in this study showed that the most common Cercospora sp. found in Thailand was C. cf. malloti, which occurred on a wide host range. The collected isolates of $C$. cf. malloti shared similar conidiophore characteristics, being thick-walled, with distinct loci formed at the apex and on the shoulders caused by conidiophore geniculation (Groenewald et al. 2013). However, there were also some variable characters, namely differences in conidiophore geniculation and conidium length, suggesting that either the DNA loci currently used are not sensitive enough to 
distinguish all species, or that different environmental conditions and hosts to some degree influence the observed Cercospora phenotype. As most isolates sporulate poorly in culture (if at all), comparisons were always done on material in vivo. Cercospora malloti was originally described from Mallotus (Euphorbiaceae) collected in the USA. Fresh material would thus need to be recollected from this host in the USA to resolve the phylogenetic relationships of this taxon. Other than these wide host range species, some taxa also appeared to be host specific, namely $C$. capsici on Capsicum spp. (Solanaceae), C. cf. mikaniicola on Mikania cordata (Asteraceae) and C. cf. zinnia on Zinnia elegans (Asteraceae). To fully resolve the taxonomy of the Cercospora spp. occurring in Thailand, however, a global initiative is called for, as the phylogenetic position of many "common" species remains unknown, and these species, like $C$. malloti, will have to be recollected on their original hosts from their respective countries of origin. Further global studies are presently underway to try and establish a phylogenetic reference tree, collection and database for the genus Cercospora.

\section{Acknowledgements}

This work was financially supported by the Royal Golden Jubilee Ph.D. Program (PHD/0061/2551) and the Thailand Research Fund (DBG5380011 and MRG5580163). J.N. also thanks the technical staff from the CBS-KNAW Fungal Biodiversity Centre for their invaluable assistance.

\section{References}

Amaradasa, B.S., Madrid, H., Groenewald, J.Z., Crous, P.W. \& Amundsen, K. (2014) Porocercospora seminalis gen. et comb. nov. the causal organism of buffalograss false smut. Mycologia 106: 77-85. http://dx.doi.org/10.3852/13-147

Arzanlou, M., Groenewald, J.Z., Fullerton, R.A., Abeln, E.C.A., Carlier, J., Zapater, M.-F., Buddenhagen, I.W., Viljoen, A. \& Crous, P.W. (2008) Multiple gene genealogies and phenotypic characters differentiate several novel species of Mycosphaerella and related anamorphs on banana. Persoonia 20: 19-37. http://dx.doi.org/10.3767/003158508X302212

Bakhshi, M., Arzanlou, M., Babai-ahari, A., Groenewald, J.Z., Braun, U. \& Crous, P.W. (2015a) Application of the consolidated species concept to Cercospora spp. from Iran. Persoonia 34: 65-86. http://dx.doi.org/10.3767/003158515X685698

Bakhshi, M., Arzanlou, M., Babai-ahari, A., Groenewald, J.Z., Braun, U. \& Crous, P.W. (2015b) Is morphology in Cercospora a reliable reflection of generic affinity? Phytotaxa 213 (1): 22-34. http://dx.doi.org/10.11646/phytotaxa.213.1.2

Bhartiya, H.D., Dubey, R.C. \& Singh, S.K. (2000) New Cercospora spp. associated with vegetable crops in north eastern Uttar Pradesh. Indian Phytopathology 53: 149-152.

Braun, U., Crous, P.W. \& Nakashima, C. (2014) Cercosporoid fungi (Mycosphaerellaceae) 2. Species on monocots (Acoraceae to Xyridaceae, excluding Poaceae). IMA Fungus 5: 203-390. http://dx.doi.org/10.5598/imafungus.2014.05.02.04

Braun, U. \& Mel'nik, V.A. (1997) Cercosporoid fungi from Russia and adjacent countries. Trudy Botanischeskogo Instituta Imeni V. L. Komarova, St. Petersburg 20: 1-130.

Braun, U., Hill, C.F. \& Schubert, K. (2006) New species and new records of biotrophic micromycetes from Australia, Fiji, New Zealand and Thailand. Fungal Diversity 22: 13-35.

Calpouzos, L. (1955) Studies on the Sigatoka disease of banana and its fungus pathogens. Cienfuegos, Atkins Garden and Research Laboratory.

Carbone, I. \& Kohn, L.M. (1999) A method for designing primer sets for speciation studies in filamentous ascomycetes. Mycologia 91: $553-556$ http://dx.doi.org/10.2307/3761358

Cheewangkoon, R., Crous, P.W., Hyde, K.D., Groenewald, J.Z. \& To-anan, C. (2008) Species of Mycosphaerella and related anamorphs on Eucalyptus leaves from Thailand. Persoonia 21: 77-91.

http://dx.doi.org/10.3767/003158508X370857

Chupp, C. (1954) A monograph of the fungus genus Cercospora. Ithaca, New York. Published by the author. 
Crous, P.W. \& Braun, U. (2003) Mycosphaerella and its anamorphs. 1. Names published in Cercospora and Passalora. [CBS Biodiversity Series no. 1.] CBS-KNAW Fungal Biodiversity Centre, Utrecht.

Crous, P.W., Gams, W., Stalpers, J.A., Robert, V. \& Stegehuis, G. (2004) MycoBank: an online initiative to launch mycology into the 21 st century. Studies in Mycology 50: 19-22.

Crous, P.W., Verkley, G.J.M., Groenewald, J.Z. \& Samson, R.A. (Eds.) (2009) Fungal biodiversity. [CBS Laboratory Manual Series no. 1]. CBS-KNAW Fungal Biodiversity Centre, Utrecht.

Crous, P.W., Braun, U., Hunter, G.C., Wingfield, M.J., Verkley, G.J., Shin, H.-D., Nakashima, C. \& Groenewald, J.Z. (2013) Phylogenetic lineages in Pseudocercospora. Studies in Mycology 75: 37-114. http://dx.doi.org/10.3114/sim0005

de Hoog, G.S. \& Gerrits van den Ende, A.H.G. (1998) Molecular diagnostics of clinical strains of filamentous Basidiomycetes. Mycoses 41: 183-189. http://dx.doi.org/10.1111/j.1439-0507.1998.tb00321.x

Drummond, A.J., Ashton, B., Buxton, S., Cheung, M., Cooper, A., Duran, C., Field, M., Heled, J., Kearse, M., Markowitz, S., Moir, R., Stones-Havas, S., Sturrock, S., Thierer, T. \& Wilson, A. (2011) Geneious v5.4. Available from: http://www.geneious.com/ (accessed 12 October 2015)

Giatgong, P. (1980) Host index of plant diseases of Thailand. Mycology Section, Plant Pathology and Microbiology Division, Department of Agriculture, Bangkok, Thailand.

Groenewald, J.Z., Groenewald, M., Braun, U. \& Crous, P.W. (2010) Cercospora speciation and host range. In: Lartey, R.T., Weiland, J.J., Panella, L., Crous, P.W. \& Windels, C.E. (Eds.) Cercospora leaf spot of sugar beet and related species. APS Press, Minnesota, USA, pp. 21-37.

Groenewald, J.Z., Nakashima, C., Nishikawa, J., Shin, H.-D., Park, J.-H., Jama, A.N., Groenewald, M., Braun, U. \& Crous, P.W. (2013) Species concepts in Cercospora: spotting the weeds among the roses. Studies in Mycology 75: 115-170. http://dx.doi.org/10.3114/sim0012

Groenewald, M., Groenewald, J.Z. \& Crous, P.W. (2005) Distinct species exist within the Cercospora apii morphotype. Phytopathology 95: 951-959.

http://dx.doi.org/10.1094/PHYTO-95-0951

Groenewald, M., Groenewald, J.Z., Braun, U. \& Crous, P.W. (2006a) Host range of Cercospora apii and C. beticola, and description of C. apiicola, a novel species from celery. Mycologia 98: 275-285. http://dx.doi.org/10.3852/mycologia.98.2.275

Groenewald, M., Groenewald, J.Z., Harrington, T.C., Abeln, E.C.A. \& Crous, P.W. (2006b) Mating type gene analysis in apparently asexual Cercospora species is suggestive of cryptic sex. Fungal Genetics and Biology 43: 813-825. http://dx.doi.org/10.1016/j.fgb.2006.05.008

Hsieh, W.H. \& Goh, T.K. (1990) Cercospora and similar fungi from Taiwan. Maw Chang Book Company. Taipei, Taiwan, Republic of China.

Hunter, G.C., Crous, P.W., Wingfield, B.D., Pongpanich, K. \& Wingfield, M.J. (2006) Pseudocercospora flavomarginata sp. nov., from Eucalyptus leaves in Thailand. Fungal Diversity 22: 71-90.

Katoh, K. \& Standley, D.M. (2013) MAFFT multiple sequence alignment software version 7: improvements in performance and usability. Molecular Biology and Evolution 30: 772-780. http://dx.doi.org/10.1093/molbev/mst010

Meeboon, J., Hidayat, I., Nakashimam, C. \& To-anun, C. (2007a) Cercospora habenariicola sp. nov. and some new records of cercosporoid fungi from Thailand. Mycotaxon 99: 117-121.

Meeboon, J., Hidayat, I. \& To-anun, C. (2007b) An annotated list of cercosporoid fungi in Northern Thailand. Journal of Agricultural Technology 3, 51-63.

Meeboon, J., Hidayat, I. \& To-anun, C. (2007c) Diversity and taxonomy of cercosporoid fungi in Thailand. In: Soytong, K. \& Hyde, K.D. (Eds.) Proceedings of the International Conference on Integration of Science and Technology for Sustainable Development (ICIST) "Biological Diversity, Food and Agricultural Technology". KMITL, Bangkok, Thailand, pp. 273-278.

Meeboon, J., Hidayat, I., To-anun, C. \& Nakashima, C. (2008) Cercosporoid fungi from Thailand II. New species of Cercospora and Passalora. Sydowia 60: 253-260.

Möller, E.M., Bahnweg, G., Sandermann, H. \& Geiger, H.H. (1992) A simple and efficient protocol for isolation of high molecular weight DNA from filamentous fungi, fruit bodies, and infected plant tissues. Nucleic Acids Research 20: 6115-6116. http://dx.doi.org/10.1093/nar/20.22.6115

Nakashima, C., Motohashi, K., Meeboon, J. \& To-anun, C. (2007) Studies on Cercospora and allied genera in northern Thailand. Fungal Diversity 26: 257-270.

Nylander, J.A.A. (2004) MrModeltest 2.0. Program distributed by the author, Uppsala University, Uppsala, Sweden. 
Petcharat, V. \& Kanjanamaneesathian, M. (1989) Species of plant pathogen Cercospora in Southern Thailand. Thai Phytopathology 9: 23-27.

Phengsintham, P., Braun, U., McKenzie, E.H.C., Chukeatirote, E., Cai, L. \& Hyde, K.D. (2013) Monograph of cercosporoid fungi from Thailand. Plant Pathology \& Quarantine 3: 67-138.

Rayner, R.W. (1970) A mycological colour chart. CMI and British Mycological Society, Kew, Surrey, England.

Ronquist, F., Teslenko, M., van der Mark, P., Ayres, D.L., Darling, A., Höhna, S., Larget, B., Liu, L., Suchard, M.A. \& Huelsenbeck, J.P. (2012) MrBayes 3.2: Efficient Bayesian phylogenetic inference and model choice across a large model space. Systematic Biology 61: 539-542.

http://dx.doi.org/10.1093/sysbio/sys029

Shin, H.D. \& Kim, J.D. (2001) Cercospora and allied genera from Korea. Plant Pathology of Korea 7. National Institute of Agricultural Science and Technology, Suwon.

Sontirat, P., Phitakpraiwan, P., Choonbamroong, W. \& Kueprakone, U. (1980) Plant pathogenic Cercosporae in Thailand. Department of Agriculture, Ministry of Agriculture and Cooperative, Bangkok, Thailand.

Tamura, K., Peterson, D., Peterson, N., Stecher, G., Nei, M. \& Kumar, S. (2011) MEGA5: Molecular evolutionary genetics analysis using maximum likelihood, evolutionary distance, and maximum parsimony methods. Molecular Biology and Evolution 28: 2731-2739. http://dx.doi.org/10.1093/molbev/msr121

Thirumalachar, M.J. \& Govindu, H.C. (1962) Notes on some Indian cercosporae. Sydowia 16: 284-288.

To-anun, C., Hidayat, I. \& Meeboon, J. (2010) Cercospora christellae, a new cercosporoid fungus associated with weed Christella parasitica from northern Thailand. Journal of Agricultural Technology 6: 331-339.

To-anun, C., Hidayat, I. \& Meeboon, J. (2011) Genus Cercospora in Thailand: taxonomy and phylogeny (with a dichotomous key to species). Plant Pathology \& Quarantine 1: 11-87.

Vasudeva, R.S. (1963) India cercosporae. Indian Council of Agricultural Research, New Delhi.

White, T.J., Bruns, T. \& Taylor, J. (1990) Amplification and direct sequencing of fungal ribosomal RNA genes for phylognetics. In: Innis, M.A., Gelfand, D.H., Sninsky, J.J. \& White, J.W. (Eds.) A Guide to Molecular Methods and Applications. Academic Press, New York, pp. 315-322. 